\title{
Proton-Coupled Electron Transfer Enhances the Electrocatalytic Reduction of Nitrite to NO in a Bioinspired Copper Complex
}

\author{
Giacomo Cioncoloni, ${ }^{\dagger, \S}$ Isolda Roger, ${ }^{\dagger, \S}$ Paul S. Wheatley, ${ }^{\ddagger}$ Claire Wilson, ${ }^{\dagger}$ Russell E. Morris, ${ }^{\dagger}$
} Stephen Sproules, ${ }^{\dagger \odot}$ and Mark D. Symes ${ }^{*} \dagger \odot$

${ }^{\dagger}$ WestCHEM, School of Chemistry, University of Glasgow, University Avenue, Glasgow G12 8QQ, United Kingdom

${ }^{\ddagger}$ EaStCHEM School of Chemistry, University of St Andrews, Purdie Building, St Andrews KY16 9ST, United Kingdom

\section{Supporting Information}

ABSTRACT: The selective and efficient electrocatalytic reduction of nitrite to nitric oxide (NO) is of tremendous importance, both for the development of NO-release systems for biomedical applications and for the removal of nitrogen oxide pollutants from the environment. In nature, this transformation is mediated by (among others) enzymes known as the copper-containing nitrite reductases. The development of synthetic copper complexes that can reduce nitrite to NO has therefore attracted considerable interest. However, there are no studies
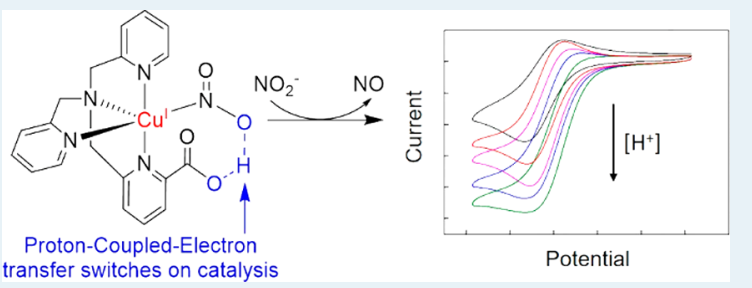
describing the crucial role of proton-coupled electron transfer during nitrite reduction when such synthetic complexes are used. Herein, we describe the synthesis and characterization of two previously unreported $\mathrm{Cu}$ complexes (3 and 4$)$ for the electrocatalytic reduction of nitrite to $\mathrm{NO}$, in which the role of proton-relaying units in the secondary coordination sphere of the metal can be probed. Complex 4 bears a pendant carboxylate group in close proximity to the copper center, while complex 3 lacks such functionality. Our results suggest that complex 4 is twice as effective an electrocatalyst for nitrite reduction than is complex 3 and that complex 4 is the best copper-based molecular electrocatalyst for this reaction yet discovered. The differences in reactivity between 3 and $\mathbf{4}$ are probed using a range of electrochemical, spectroscopic, and computational methods, which shed light on the possible catalytic mechanism of $\mathbf{4}$ and implicate the proton-relaying ability of its pendant carboxylate group in the enhanced reactivity that this complex displays. These results highlight the critical role of proton-coupled electron transfer in the reduction of nitrite to $\mathrm{NO}$ and have important implications for the design of biomimetic catalysts for the selective interconversions of the nitrogen oxides.

KEYWORDS: nitrite reduction, nitric oxide, copper nitrite reductase mimic, electrocatalysis, proton-coupled-electron transfer

\section{INTRODUCTION}

The reduction of nitrite $\left(\mathrm{NO}_{2}^{-}\right)$to nitric oxide (NO) in the bloodstream is potentially a physiological source of $\mathrm{NO}{ }^{1}$ which plays an important role in neurotransmission and vasodilation..$^{2-4}$ Nitrite reduction to $\mathrm{NO}$ is also a key step in the natural nitrogen cycle, being part of the process of bacterial denitrification. ${ }^{5}$ There are a number of classes of enzyme that perform this transformation, including those using hemes, molybdenum and copper centers as the catalytic species. In the case of $\mathrm{Cu}$, the enzymes performing this reaction are known collectively as the copper-containing nitrite reductases (CuNIR), and the reaction that they mediate is summarized in eq $1 .^{6}$

$$
\mathrm{Cu}(\mathrm{I})+\mathrm{NO}_{2}{ }^{-}+2 \mathrm{H}^{+} \rightarrow \mathrm{Cu}(\mathrm{II})+\mathrm{NO}+\mathrm{H}_{2} \mathrm{O}
$$

In 1991, Adman and co-workers were the first to determine the crystal structure of a CuNIR-type enzyme, ${ }^{7}$ which showed that the active site for the reduction of $\mathrm{NO}_{2}{ }^{-}$consists of a $\mathrm{Cu}(\mathrm{II})$ ion coordinated by three histidine ligands and a single water molecule, giving a distorted-tetrahedral geometry at the copper center. These results have been confirmed by subsequent studies, ${ }^{8,9}$ which have also given insight into the nature of nitrite binding during catalysis. At the present time, there is some debate over the precise order of events during nitrite reduction to $\mathrm{NO}$ with $\mathrm{CuNIR}^{5}$

One possibility is that nitrite displaces the bound water from the $\mathrm{Cu}$ (II) center in CuNIR, forming a complex in which the $\mathrm{NO}_{2}{ }^{-}$is bound to $\mathrm{Cu}(\mathrm{II})$ through both of its oxygen atoms (and hence the $\mathrm{Cu}$ (II) adopts a geometry akin to a squarebased pyramid; see Scheme 1). ${ }^{5,10}$ Subsequent electron and proton transfer steps then lead to $\mathrm{N}-\mathrm{O}$ bond scission and ultimately the loss of one of the nitrite-derived oxygens as water. Alternatively, reduction of the copper center may occur before nitrite binds. In any case, a nitrite-bound $\mathrm{Cu}(\mathrm{I})$ center is obtained, from which $\mathrm{NO}$ is liberated with concomitant regeneration of the original $\mathrm{Cu}$ (II) complex (in its waterbound form), ready to re-enter the catalytic cycle. ${ }^{11,12}$

On account of the comparatively simple active site structure of CuNIR suggested by the crystallographic studies, a number of groups have developed simplified analogues of this enzyme

Received: January 27, 2018

Revised: April 17, 2018

Published: April 25, 2018 
Scheme 1. Simplified Proposed Mechanism for Nitrite Reduction to Nitric Oxide by $\mathrm{CuNIR}^{a}$

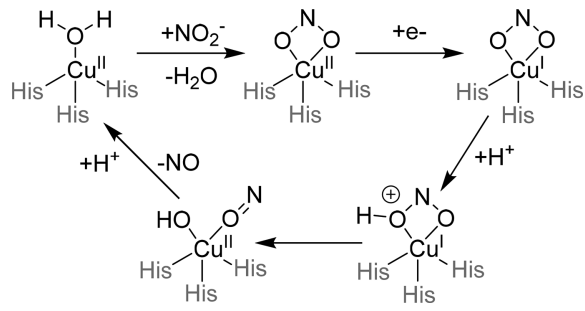

${ }^{a}$ The histidine ligands are abbreviated as "His" and are shown in gray.

based on tripodal $\mathrm{N}$-donor ligands coordinated to a $\mathrm{Cu}$ center. $^{11,13-45}$ In many cases, these analogues also encapsulate the functionality of CuNIR (and so can mediate the reduction of nitrite to NO), normally with the use of stoichiometric sacrificial electron donors. There is also a distinct subset of such $\mathrm{Cu}-\mathrm{N}$ donor complexes that can mediate the electrocatalytic reduction of nitrite to $\mathrm{NO} .^{46-51}$ In these latter cases in particular, the role of solution $\mathrm{pH}$ (or the presence of additional proton sources in nonaqueous media) has been shown to be critical, with acidic regimes being essential for catalytic reduction of nitrite to NO. This is perhaps not surprising, given the dependence of eq 1 on the presence of protons. More surprising to us, especially considering that protons are required for this reduction, was the relative dearth of studies on the role of proton-relay units that might mediate proton-coupled electron transfer $(\mathrm{PCET})^{52-56}$ during catalytic nitrite reduction with such CuNIR mimics.

In the natural CuNIR class of enzymes, an aspartate residue sits in close proximity to the bound nitrite and helps to mediate proton transfer to one of the nitrite oxygens, which is eventually lost as water. ${ }^{5,10}$ The importance of nearby proton-donating residues in the mechanism of nitrite reduction by CuNIR has been highlighted by recent crystallographic ${ }^{57}$ and site-directed mutagenesis ${ }^{58}$ studies on the relevant enzymes. There have also been three seminal papers in recent years showcasing the importance of hydrogen bonding in the secondary coordination sphere of synthetic systems for nitrite reduction based on both iron ${ }^{59,60}$ and copper, ${ }^{61}$ although none of these systems were able to demonstrate catalytic turnover. However, to the best of our knowledge, there exist no examples of synthetic, small-molecule platforms for the catalytic reduction of nitrite to $\mathrm{NO}$ where the role of proton relays has been addressed explicitly, as it has been, for example, with synthetic platforms for catalytic proton reduction, ${ }^{62-67}$ water oxidation, ${ }^{68-70}$ and $\mathrm{CO}_{2}$ reduction. ${ }^{71,72}$

Herein we report the synthesis and characterization of two new copper complexes ( 3 and 4 ) which allow the role of PCET in the electrocatalytic reduction of nitrite to NO with synthetic, small-molecule platforms to be addressed for the first time. Both complexes contain a copper center ligated by a tetradentate tris(2-methylpyridyl)amine (TMPA) ligand, and both are competent for the electrocatalytic reduction of nitrite to NO in nonaqueous solvent. However, complex 4 (in which a carboxylate group is positioned in close proximity to nitrite bound to the copper center), is roughly twice as effective a catalyst for this transformation as complex 3, which lacks any such proton-relaying groups. We probe and rationalize these differences in reactivity using a range of electrochemical, spectroscopic, and computational methods, which together shed light on the possible mechanism of reaction. Our results suggest that the incorporation of PCET-competent groups in the secondary coordination sphere of the metal center gives rise to a considerable enhancement in the rate of electrocatalytic nitrite reduction and hence give insights into the workings of the natural CuNIR enzymes and suggest new avenues for the development of biomimetic catalysts for applications such as the removal of $\mathrm{NO}_{2}^{-}$from wastewater streams ${ }^{73}$ and NOrelease systems for biomedical applications. ${ }^{74}$

\section{RESULTS AND DISCUSSION}

Synthesis and Crystallography. The general synthetic route for the formation of complexes 3 and 4 is shown in Scheme 2. Hence, 6-chloromethylpyridine-2-carboxylic acid methyl ester was prepared via the procedure of Mato-Iglesias et al. $^{75}$ The synthesis of compound 1 (see Figure S1) was then achieved by reaction of this methyl ester with bis(2pyridylmethyl)amine according to the procedure used by Kotani et al. for the preparation of the allied ethyl ester. ${ }^{76}$ Compound 1 could then be hydrolyzed to yield the known acid

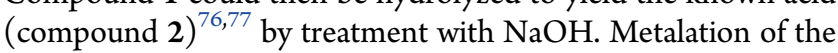
acid and ester ligands was then achieved accordingly to adapted literature procedures, ${ }^{46,78}$ generating the new complexes [3$\left.\mathrm{H}_{2} \mathrm{O}\right]^{2+}$ and $\left[4-\mathrm{H}_{2} \mathrm{O}\right]^{+}$(see the Experimental Section).

After dissolution in $\mathrm{CH}_{3} \mathrm{CN}$, dark blue crystals of the acetonitrile adduct of complex $3\left[3-\mathrm{CH}_{3} \mathrm{CN}\right]\left(\mathrm{ClO}_{4}\right)_{2}$ were obtained after standing at room temperature for 3 weeks. These

Scheme 2. Synthetic Route To Obtain Complexes $\left[3-\mathrm{H}_{2} \mathrm{O}\right]^{2+}$ and $\left[4-\mathrm{H}_{2} \mathrm{O}\right]^{+}$

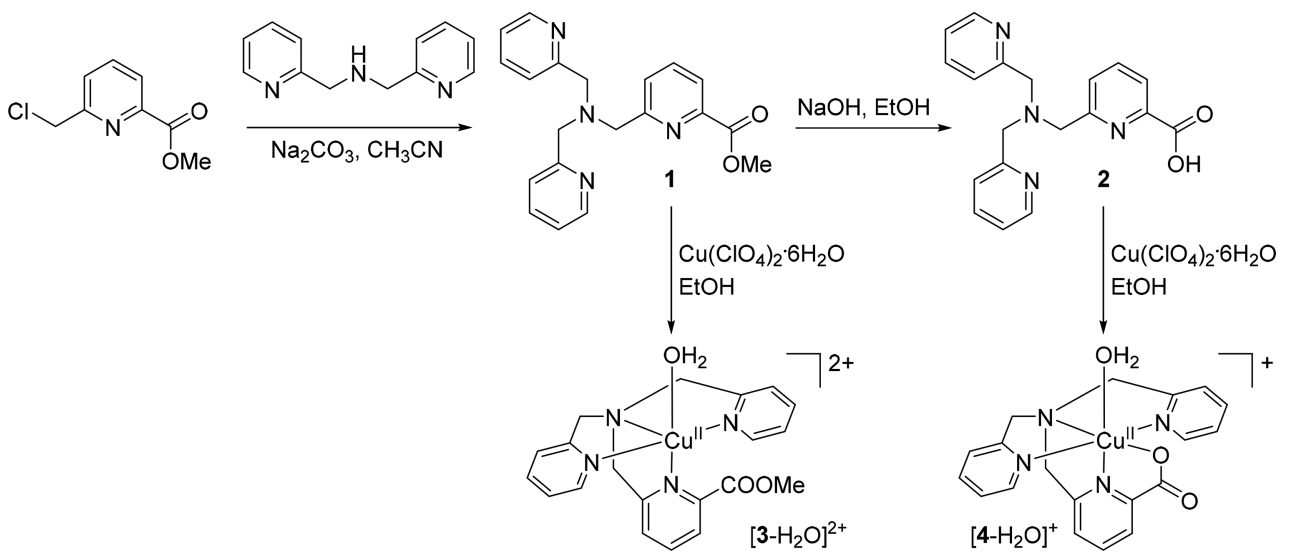


crystals proved to be of suitable quality for X-ray diffraction, allowing the structure shown in Figure 1 to be obtained.
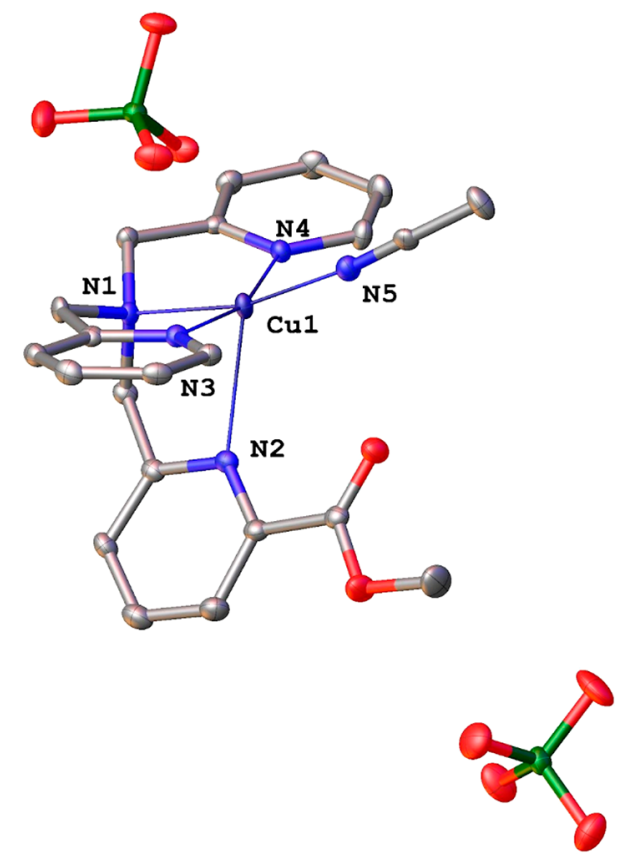

Figure 1. Molecular structure of $\left[3-\mathrm{CH}_{3} \mathrm{CN}\right]\left(\mathrm{ClO}_{4}\right)_{2}$. Further crystallographic details can be found in the Supporting Information. Ellipsoids are drawn at the $50 \%$ probability level. Color scheme: C, gray; N, blue; $\mathrm{O}$, red; $\mathrm{Cl}$, green; $\mathrm{Cu}$, purple. For selected bond lengths and angles, see Table 1. Hydrogen atoms are omitted.

The presence of two perchlorate anions per $\mathrm{Cu}$ complex indicated that the copper center remained in the $+\mathrm{II}$ oxidation state. Typically, $\mathrm{Cu}$ (II) complexes with tris(2-methylpyridyl)amine (TMPA) ligands adopt a distorted-trigonal-bipyramidal geometry, whereby the $\mathrm{Cu}-\mathrm{N}_{(\text {pyridyl)TMPA }}$ bonds define the triangular plane (with typical lengths between 2.0 and $2.1 \AA$ ) and the apexes of the bipyramid consist of a rather short $\mathrm{Cu}-$

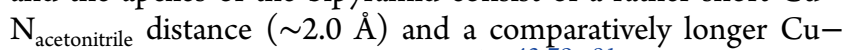
$\mathrm{N}_{\text {(alkyl)TMPA }}$ interaction $(\sim 2.4 \AA) .{ }^{43,79-81}$ However, the geometry of $\left[3-\mathrm{CH}_{3} \mathrm{CN}\right]^{2+}$ is more akin to that of a squarebased pyramid ( $\tau$ value $\sim 0.1$ on the scale of Addison and Reedijk ${ }^{82}$ ), with N2 as its apex (see selected bond lengths and angles in Table 1). This gives $\mathrm{Cu}-\mathrm{N}$ bond lengths in the square plane of between 2.045(2) and 1.972(2) $\AA$, while the $\mathrm{Cu}-\mathrm{N} 2$ interaction appears to be only very weak $(\mathrm{Cu} 1-\mathrm{N} 2=2.473(2)$ $\AA)$. That said, Figure 1 shows that the lone pair on the N2 nitrogen is clearly directed toward the $\mathrm{Cu}$ (II) center. It is noteworthy that this elongation in the $\mathrm{Cu}-\mathrm{N} 2$ distance occurs for the pyridine which bears the methyl ester substituent

Table 1. Experimental Bond Distances $(\AA)$ and Angles (deg) in $\left[3-\mathrm{CH}_{3} \mathrm{CN}\right]^{2+}$

$\begin{array}{cclc}\mathrm{Cu} 1-\mathrm{N} 1 & 2.045(2) & \mathrm{Cu} 1-\mathrm{N} 4 & 1.981(2) \\ \mathrm{Cu} 1-\mathrm{N} 2 & 2.473(2) & \mathrm{Cu} 1-\mathrm{N} 5 & 1.984(3) \\ \mathrm{Cu} 1-\mathrm{N} 3 & 1.972(2) & & \\ \mathrm{N} 1-\mathrm{Cu} 1-\mathrm{N} 2 & 77.49(9) & \mathrm{N} 4-\mathrm{Cu} 1-\mathrm{N} 1 & 82.6(1) \\ \mathrm{N} 3-\mathrm{Cu} 1-\mathrm{N} 1 & 84.5(1) & \mathrm{N} 4-\mathrm{Cu} 1-\mathrm{N} 2 & 110.26(9) \\ \mathrm{N} 3-\mathrm{Cu} 1-\mathrm{N} 2 & 79.14(9) & \mathrm{N} 4-\mathrm{Cu} 1-\mathrm{N} 5 & 92.9(1) \\ \text { N3-Cu1-N4 } & 161.9(1) & \mathrm{N} 5-\mathrm{Cu} 1-\mathrm{N} 1 & 166.0(1) \\ \mathrm{N} 3-\mathrm{Cu} 1-\mathrm{N} 5 & 96.6(1) & \mathrm{N} 5-\mathrm{Cu} 1-\mathrm{N} 2 & 116.45(9)\end{array}$

adjacent to the $\mathrm{N}$ donor. This arrangement is rather reminiscent of the geometry previously observed by Tanaka and co-workers for the complex $\left[\mathrm{CuCl}\left(\mathrm{Me}_{1} \mathrm{TMPA}\right)\right]^{+}$, where the TMPA pyridine bearing the methyl group exhibited a much longer $\mathrm{Cu}-\mathrm{N}$ interaction than the unsubstituted pyridines $(2.337 \AA$ vs $\sim 1.99 \AA) .{ }^{46}$ On account of the differing electronic properties of methyl and methyl ester substituents, it therefore seems likely that this common bond elongation effect is the result of steric crowding brought about by the close proximity of the substituents to the $\mathrm{N}$-donor atom. ${ }^{83}$ Similarly long $\mathrm{Cu}-$ $\mathrm{N}$ interactions have also been noted before in $\mathrm{Cu}$ (II) tris(2methylpyridyl)amine complexes bearing bulky substituents next to the $\mathrm{N}$ donors (albeit where the ligands were more symmetrically substituted) by Reinaud and co-workers. ${ }^{84}$ The shortest distance between the $\mathrm{Cu}$ center in $\left[3-\mathrm{CH}_{3} \mathrm{CN}\right]^{2+}$ and any of the oxygens on the nearest perchlorate anion is $2.745 \AA$, suggesting only a very weak interaction between the $\mathrm{Cu}$ and perchlorate and therefore that the metal center is best considered as five-coordinate.

When tetrabutylammonium nitrite $\left(\mathrm{TBA}-\mathrm{NO}_{2}\right)$ was added to solutions of complexes $\mathbf{3}$ and $\mathbf{4}$ in acetonitrile, the initially blue solutions immediately turned green (see Figure 2), indicating coordination of the $\mathrm{Cu}(\mathrm{II})$ center to nitrite in both cases. ${ }^{42}$

Green crystals of complex 4 bound to nitrite were isolated from an acetonitrile solution of this complex in the presence of 5 equiv of TBA- $\mathrm{NO}_{2}$ and 1 equiv of benzoic acid. X-ray diffraction on these crystals revealed a structure in which nitrite is bound to the copper center through nitrogen, while the carboxylate group remains coordinated to $\mathrm{Cu}$, giving an overall neutral species (with no further counterions present), which we formulate as $\left[4-\mathrm{NO}_{2}\right]$ (see Figure 3). Hence, although acid was added to the crystallization medium, there is no evidence that the complex is protonated under these conditions. We note that Kojima and co-workers have previously noted the tendency for this carboxylate group to coordinate to the metal center in their allied $\mathrm{Ru}$ and $\mathrm{Cr}$ complexes, ${ }^{76,77}$ and Lonnon et al. have similarly reported a $\mathrm{Co}$ (III) complex of ligand $\mathbf{2}$ in which the carboxylate group also coordinates to the metal center, giving a distorted-octahedral geometry at the metal. ${ }^{85}$

The geometry around the copper center in $\left[4-\mathrm{NO}_{2}\right]$ is probably best described as distorted octahedral, with a JahnTeller elongation along the $\mathrm{N} 1-\mathrm{Cu}-\mathrm{O} 1$ axis. This leads to a rather long $\mathrm{Cu}-\mathrm{N} 1$ distance $(2.384(2) \AA)$, while the $\mathrm{Cu}-$ $\mathrm{N}_{\text {pyridyl }}$ lengths are all significantly shorter $(2.047(2)-2.031(2)$ $\AA$ ) and more similar to the $\mathrm{Cu}-\mathrm{N} 1 \mathrm{~N}$ distance between the copper center and the bound nitrite (1.983(3) $\AA$ ). It is these $\mathrm{Cu}-\mathrm{N}_{\text {pyridyl }}$ and $\mathrm{Cu}-\mathrm{N} 1 \mathrm{~N}$ interactions that define the equator of the distorted octahedron (with roughly $90^{\circ}$ angles between them; see Table 2), while the second axial position is occupied by $\mathrm{O} 1(\mathrm{Cu}-\mathrm{O} 1=2.205(2) \AA)$. However, as the bond angles in Table 2 show, O1 does not sit directly over the center of the equatorial plane but rather is skewed toward N2.

Two somewhat allied $\mathrm{Cu}(\mathrm{II})$ complexes which incorporate a TMPA ligand bearing a carboxylate group that binds to the metal center have been reported by Suzuki and co-workers, ${ }^{86,87}$ although in both of these structures the metal has only five coordination interactions (i.e., there is no coordinated nitrite or similarly small molecule) and so the $\mathrm{Cu}(\mathrm{II})$ adopts a squarepyramidal geometry. Meanwhile, Comba and co-workers have reported a number of structures in which $\mathrm{Cu}(\mathrm{II})$ is supported by a TMPA-like ligand (which also bears a carboxylate group which coordinates to the metal), ${ }^{88,89}$ but where the linkage between the pyridine groups is a bispidine unit. This then 

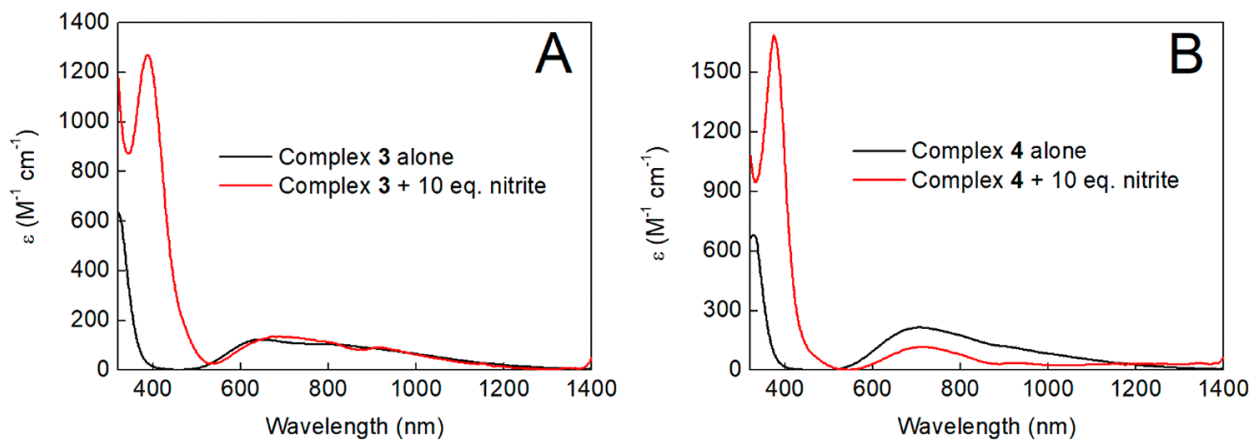

Figure 2. (A) Overlay of the electronic spectra of complex 3 in acetonitrile (black line) and of this complex after the addition of 10 equiv of TBA$\mathrm{NO}_{2}$ (also in acetonitrile, red line). (B) Overlay of the electronic spectra of complex 4 in acetonitrile (black line) and of this complex after the addition of 10 equiv of $\mathrm{TBA}-\mathrm{NO}_{2}$ (also in acetonitrile, red line).

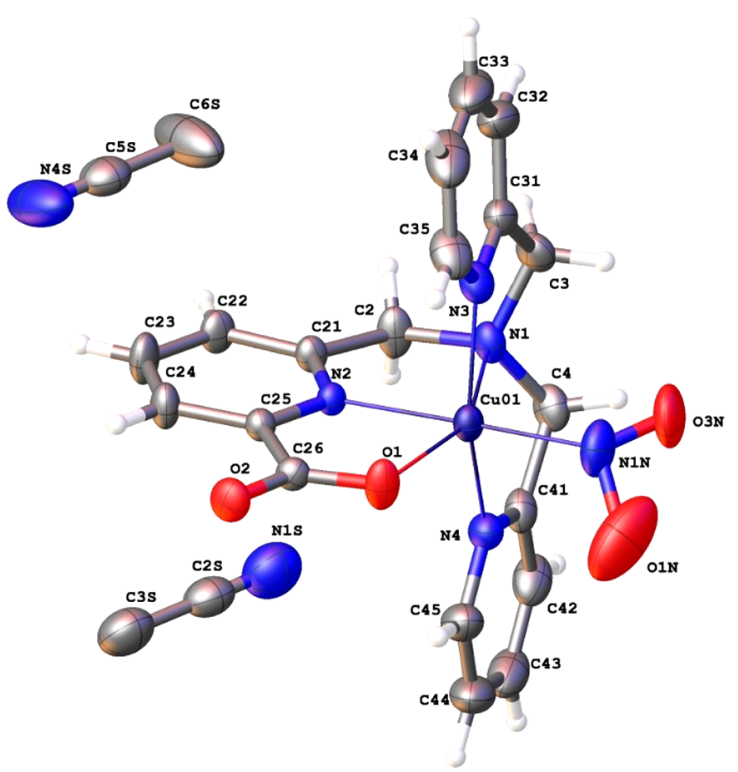

Figure 3. Molecular structure of $\left[4-\mathrm{NO}_{2}\right]$. Further crystallographic details can be found in the Supporting Information. Ellipsoids are drawn at the $30 \%$ probability level. Color scheme: $\mathrm{C}$, gray; $\mathrm{H}$, white; $\mathrm{N}$, blue; $\mathrm{O}$, red; $\mathrm{Cu}$, purple. A minor disorder component for bound $\mathrm{NO}_{2}^{-}$has been omitted. For selected bond lengths and angles, see Table 2.

Table 2. Experimental Bond Distances ( $\AA$ ) and Angles (deg) in $\left[4-\mathrm{NO}_{2}\right]$

$\begin{array}{lrlr}\mathrm{Cu} 01-\mathrm{O} 1 & 2.205(2) & \mathrm{Cu} 01-\mathrm{N} 3 & 2.047(2) \\ \mathrm{Cu} 01-\mathrm{N} 1 & 2.384(2) & \mathrm{Cu} 01-\mathrm{N} 4 & 2.039(2) \\ \mathrm{Cu} 01-\mathrm{N} 2 & 2.031(2) & \mathrm{Cu} 01-\mathrm{N} 1 \mathrm{~N} & 1.983(3) \\ \mathrm{O} 1-\mathrm{Cu} 01-\mathrm{N} 1 & 154.03(7) & \mathrm{N} 4-\mathrm{Cu} 01-\mathrm{N} 1 & 76.05(8) \\ \mathrm{N} 2-\mathrm{Cu} 01-\mathrm{O} 1 & 76.67(7) & \mathrm{N} 4-\mathrm{Cu} 01-\mathrm{N} 3 & 152.5(1) \\ \mathrm{N} 2-\mathrm{Cu} 01-\mathrm{N} 1 & 77.37(8) & \mathrm{N} 1 \mathrm{~N}-\mathrm{Cu} 01-\mathrm{O} 1 & 98.8(1) \\ \mathrm{N} 2-\mathrm{Cu} 01-\mathrm{N} 3 & 88.49(7) & \mathrm{N} 1 \mathrm{~N}-\mathrm{Cu} 01-\mathrm{N} 1 & 107.1(1) \\ \mathrm{N} 2-\mathrm{Cu} 01-\mathrm{N} 4 & 92.37(7) & \mathrm{N} 1 \mathrm{~N}-\mathrm{Cu} 01-\mathrm{N} 2 & 175.2(1) \\ \mathrm{N} 3-\mathrm{Cu} 01-\mathrm{O} 1 & 101.32(8) & \mathrm{N} 1 \mathrm{~N}-\mathrm{Cu} 01-\mathrm{N} 3 & 90.9(1) \\ \mathrm{N} 3-\mathrm{Cu} 01-\mathrm{N} 1 & 77.29(8) & \mathrm{N} 1 \mathrm{~N}-\mathrm{Cu} 01-\mathrm{N} 4 & 90.3(1) \\ \mathrm{N} 4-\mathrm{Cu} 01-\mathrm{O} 1 & 105.68(8) & & \end{array}$

affords structures in which the metal center forms six coordination interactions (one to each of the three pyridines, one to the carboxylate oxygen, and one to each of the two amines in the bispidine system), giving distorted-octahedral geometries. Again, however, there is no interaction between the metal center and any small molecules (such as the nitrite in Figure 3). Hence, the structure reported here for $\left[4-\mathrm{NO}_{2}\right]$ appears to be unique in showing a $\mathrm{Cu}$ (II) center ligated by a TMPA-derived ligand, and which is also coordinated to both nitrite and carboxylate.

EPR and IR Spectroscopy of Complexes 3 and 4. Complexes 3 and $\mathbf{4}$ are paramagnetic with an $S=1 / 2$ ground state. Their EPR spectra recorded in $\mathrm{CH}_{3} \mathrm{CN}$ solution at room temperature are very similar (Figures S2a and S3a), exhibiting the hallmark four-line pattern resulting from the hyperfine coupling of the $\mathrm{Cu}$ (II) electron spin with the $I=3 / 2$ nuclear spin of the ${ }^{63,65} \mathrm{Cu}$ isotopes ( $100 \%$ natural abundance). Their similarity is underscored by the near-identical spin-Hamiltonian parameters obtained from spectral simulation, with $g_{\text {iso }}=2.122$ and $A_{\text {iso }}=57 \times 10^{-4} \mathrm{~cm}^{-1}$ for 3 and $g_{\text {iso }}=2.123, A_{\text {iso }}=55 \times$ $10^{-4} \mathrm{~cm}^{-1}$ for 4 . The large line width obscures any additional splitting from the spin-active ${ }^{14} \mathrm{~N}(I=1,99.7 \%$ natural abundance) atoms in the ligands and derives from the rates of tumbling of the molecules in solution. Given the presence of a coordinated acetonitrile in the crystal structure (vide supra), we assign these species as being $\left[3-\mathrm{NCCH}_{3}\right]^{2+}$ and $\left[4-\mathrm{NCCH}_{3}\right]^{+}$ complex ions in solution, though there will likely be species without the solvent ligand that will have similar parameters that contribute to the line width. Interestingly, treating these samples with an excess of benzoic acid (Figures S2b and S3b) does not alter the spectral profile, confirming that the carboxylate group in complex 4 does not become protonated under these conditions (i.e., the bulk of the sample is the carboxylate-bound version of complex 4).

Upon treating solutions of $\left[3-\mathrm{NCCH}_{3}\right]^{2+}$ and $\left[4-\mathrm{NCCH}_{3}\right]^{+}$ with excess $\mathrm{TBA}-\mathrm{NO}_{2}$, the resulting EPR spectra exhibit rather different profiles (Figures S2c and S3c). In the case of complex 3, the EPR spectrum that is obtained shows only a slight change from that of $\left[3-\mathrm{NCCH}_{3}\right]^{2+}\left(g_{\text {iso }}=2.130\right.$ and $A_{\text {iso }}=53 \times 10^{-4}$ $\mathrm{cm}^{-1}$ ), with the increase in $g$ value being commensurate with replacement of $\mathrm{CH}_{3} \mathrm{CN}$ by $\mathrm{NO}_{2}^{-}$. Hence, the EPR data suggest that nitrite is bound to give a species of the form $\left[3-\mathrm{NO}_{2}\right]^{+}$. In contrast, when $\left[4-\mathrm{NCCH}_{3}\right]^{+}$is treated with excess $\mathrm{TBA}-\mathrm{NO}_{2}$, the resulting spectrum of $\left[4-\mathrm{NO}_{2}\right]$ is featureless with rampant line broadening that drowns out the hyperfine features (Figure S3c). This is either the result of attenuated molecular tumbling in this solvent medium or overlapping spectra from various isomers and conformations of two or more species.

To gain more information on the nature of complexes 3 and 4 in solution in the presence of acid and nitrite, dichloromethane was added to the solution samples of $\left[3-\mathrm{NCCH}_{3}\right]^{2+}$ and $\left[4-\mathrm{NCCH}_{3}\right]^{+}$to produce homogeneous frozen glasses for 
measurements at $150 \mathrm{~K}$. The spectrum of $\left[3-\mathrm{NCCH}_{3}\right]^{2+}$ is quintessentially that of a $\mathrm{Cu}$ (II) species with an unpaired electron in the $\mathrm{d}_{x^{2}-y^{2}}$ orbital (Figure S4a). The spectrum yielded axial spin-Hamiltonian parameters $g=(2.054,2.083,2.226)$ and $A_{\mathrm{Cu}}=(-6,-6,180) \times 10^{-4} \mathrm{~cm}^{-1}$ where the average values, $\langle g\rangle$ $=2.121$ and $\langle A\rangle=56 \times 10^{-4} \mathrm{~cm}^{-1}$, nicely match the isotropic parameters and so confirm that a single dominant species is present at both $150 \mathrm{~K}$ and room temperature. The benzoic acid treated sample of $\left[3-\mathrm{NCCH}_{3}\right]^{2+}$ reveals some differences in the frozen-solution spectrum, which we ascribe to the presence of a minor second species and aggregation effects common in $\mathrm{Cu}(\mathrm{II}) \mathrm{EPR}$ spectra (Figure S4b).

The frozen-glass EPR spectrum of $\left[3-\mathrm{NO}_{2}\right]^{+}$is shown in Figure $\mathrm{S} 4 \mathrm{c}$ and is dominated by a signal with $g=(2.044,2.102$, $2.247)$ and $A_{\mathrm{Cu}}=(10,14,144) \times 10^{-4} \mathrm{~cm}^{-1}$. These values are consistent with nitrite binding to copper through oxygen in a quasi-bidentate manner (i.e., as $\left[\mathrm{Cu}\left(\kappa^{2}-\mathrm{ONO}\right)\right.$ (TMPA$\left.\left.\left.\mathrm{CO}_{2} \mathrm{Me}\right)\right]\right)$. The spectrum in Figure $\mathrm{S} 4 \mathrm{c}$ also has a $5 \%$ contribution from a species containing two nitrites, $\left[\mathrm{Cu}\left(\kappa^{1}\right.\right.$ $\left.\mathrm{NO}_{2}\right)\left(\kappa^{2}-\mathrm{ONO}\right)\left(\right.$ TMPA- $\left.\left.\mathrm{CO}_{2} \mathrm{CH}_{3}\right)\right]$. This second subspectrum has $g=(2.053,2.059,2.312), A_{\mathrm{Cu}}=(0,24,162) \times 10^{-4} \mathrm{~cm}^{-1}$, $A_{\mathrm{N}}=(0,20,0) \times 10^{-4} \mathrm{~cm}^{-1}$, and $A_{\mathrm{N}}=(0,18,0) \times 10^{-4} \mathrm{~cm}^{-1}$ and is identical with those we previously reported for the complex $\left[\mathrm{Cu}\left(\kappa^{1}-\mathrm{NO}_{2}\right)\left(\kappa^{2}\right.\right.$-ONO$)(6$-methyltris (2-pyridyl)methanol methyl ester) $]^{42}$ The occurrence of a similar species in the current case is readily apparent due to its narrow lines in the frozen glass that are indicative of anisotropic coupling to two different ${ }^{14} \mathrm{~N}$ nuclei, one for the $\mathrm{N}$-bound $\mathrm{NO}_{2}{ }^{-}$ligand and the other for the pyridyl-N trans to the nitrite. Figure S4d shows that, when benzoic acid is added to this sample, very little change is observed in the EPR signal, suggesting that the coordination geometry remains unchanged.

The frozen solution spectrum of $\left[4-\mathrm{NCCH}_{3}\right]^{+}$in $\mathrm{CH}_{3} \mathrm{CN} /$ $\mathrm{CH}_{2} \mathrm{Cl}_{2}$ is more elaborate and consists of at least two different monocopper complexes present in the solution in addition to aggregation of these complexes in the frozen solution (Figure $\mathrm{S} 5 \mathrm{a})$. This is confirmed by using DMF as a glassing solvent (Figure S5b), which leads to an almost featureless spectrum, as this more basic solvent mixture promotes greater aggregation of the $\mathrm{Cu}$ (II) species. The absence of a half-field signal rules out dimerization of this complex: for example, through the pendant carboxylate group of the TMPA ligand. Treating $\left[4-\mathrm{NCCH}_{3}\right]^{+}$ with excess benzoic acid (Figure S5c,d) shows that one of the two monocopper species is favored over the other and also diminishes the effects of aggregation. Furthermore, these frozen-solution spectra suggest that slow tumbling (rather than multiple overlapping signals) produces the broad line observed in the room-temperature spectrum of $\left[4-\mathrm{NCCH}_{3}\right]^{+}$ treated with benzoic acid.

The spectrum of $\left[4-\mathrm{NO}_{2}\right]$ recorded in a $\mathrm{CH}_{3} \mathrm{CN} / \mathrm{CH}_{2} \mathrm{Cl}_{2}$ frozen glass is shown in Figure 4 and Figure S5e. Simulation of this spectrum reveals that it is composed of three subspectra (lower panels in Figure 4). Hence, the major species ( $82 \%$ of the spectrum, orange line in Figure 4) has been simulated with $g=(2.058,2.081,2.295)$ and $A_{\mathrm{Cu}}=(10,10,147) \times 10^{-4} \mathrm{~cm}^{-1}$, where the average $g$ value, $\langle g\rangle=2.145$, matches that from the fluid solution spectrum, $g_{\text {iso }}=2.142$, suggesting that the nitrite is bound to the copper center through nitrogen. The two minor species have been included in the fit, as their features are clearly observed, and are highly analogous to the spectra observed for $\left[3-\mathrm{NO}_{2}\right]^{+}$(Figure S4c). Hence, there is a component accounting for $15 \%$ of the spectrum with $g=(2.044,2.102$, $2.247)$ and $A_{\mathrm{Cu}}=(10,14,144) \times 10^{-4} \mathrm{~cm}^{-1}$, which we assign

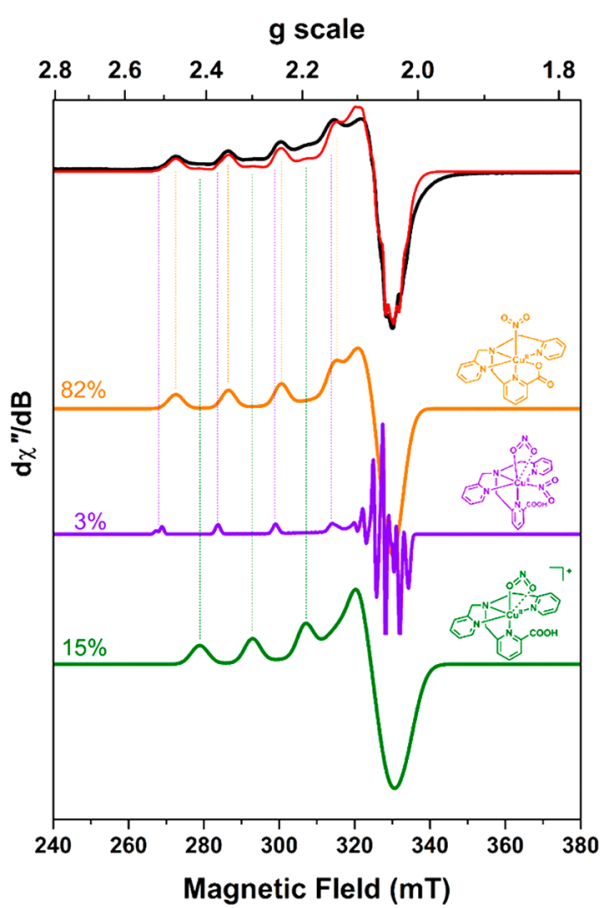

Figure 4. X-band EPR spectrum of $\left[4-\mathrm{NO}_{2}\right]$ recorded in $5 / 1 \mathrm{CH}_{3} \mathrm{CN} /$ $\mathrm{CH}_{2} \mathrm{Cl}_{2}$ solution at $150 \mathrm{~K}$ (experimental conditions: frequency, 9.430 $\mathrm{GHz}$; power, $6.3 \mathrm{~mW}$; modulation, $0.1 \mathrm{mT}$ ). Experimental data are represented by the black line. The simulation is composed of three subspectra with relevant weighting shown in orange, violet, and green lines; the sum is given by the red trace overlaid on the experimental spectrum. Guidelines map the contribution of each subspectrum to the $A_{\|}$features of the experimental spectrum.

to a quasi-bidentate O-bound species, $\left[\mathrm{Cu}\left(\kappa^{2}-\mathrm{ONO}\right)\right.$ (TMPA$\left.\left.\mathrm{CO}_{2} \mathrm{H}\right)\right]$ (green trace in Figure 4). Meanwhile, by analogy to Figure $\mathrm{S} 4 \mathrm{c}$, the smallest of the simulated components corresponds to $\left[\mathrm{Cu}\left(\kappa^{1}-\mathrm{NO}_{2}\right)\left(\kappa^{2}-\mathrm{ONO}\right)\left(\mathrm{TMPA}-\mathrm{CO}_{2} \mathrm{H}\right)\right]$ (purple trace in Figure 4). Isomerization to the weaker nitrito ligand will account for the lower $g_{\|}$value and is corroborated by calculations which show that the $\kappa^{1}-\mathrm{NO}_{2}$ and $\kappa^{2}$-ONO structures are isoenergetic (vide infra).

The spectrum of $\left[4-\mathrm{NO}_{2}\right]$ treated with excess benzoic acid (Figure S5f) is almost identical with that for $\left[4-\mathrm{NO}_{2}\right]$, except that it has a slightly different ratio of $88: 10: 2$ of the three subspectra under discussion. The dominant species is thus again assigned as $\left[4-\mathrm{NO}_{2}\right]$, where the carboxylate remains bound to the $\mathrm{Cu}$ ion in a six-coordinate environment. Despite the lack of an observable hyperfine splitting, we nevertheless assign this complex with an N-bound nitrite ligand on the basis of computational analysis (vide infra). The second subspectrum has features which closely resemble those of the frozen-solution spectrum of $\left[3-\mathrm{NO}_{2}\right]^{+}$(Figure $\mathrm{S} 4 \mathrm{c}$ ), suggesting that there is a $10 \%$ component from $\left[\mathrm{Cu}\left(\kappa^{2}-\mathrm{ONO}\right)\left(\mathrm{TMPA}-\mathrm{CO}_{2} \mathrm{H}\right)\right]$ and a $2 \%$ component from $\left[\mathrm{Cu}\left(\kappa^{1}-\mathrm{NO}_{2}\right)\left(\kappa^{2}-\mathrm{ONO}\right)\left(\mathrm{TMPA}-\mathrm{CO}_{2} \mathrm{H}\right)\right]$.

Hence, these EPR data support the assumption that nitrite binds to complex $\mathbf{4}$ in solution primarily through nitrogen, in a fashion similar to that observed in the solid state (Figure 3), although with significant minority species where the nitrite is bound through oxygen. Furthermore, the data suggest that addition of acid to $\left[4-\mathrm{NO}_{2}\right]$ does not lead to a significant change in the coordination geometry at the copper center, implying that species where the carboxylate group remains bound to the metal dominate in solution over those where the 

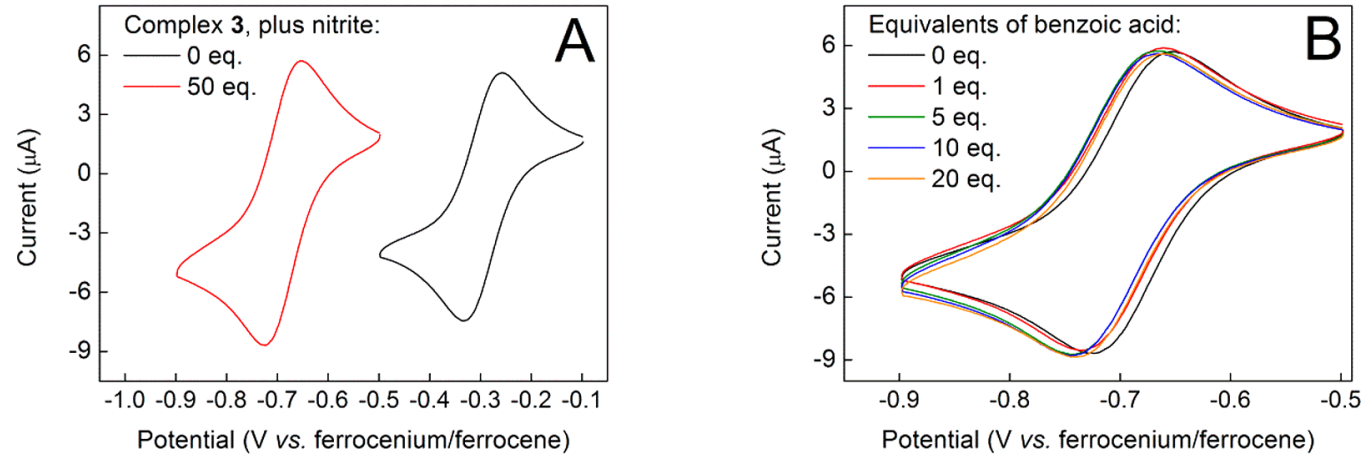

Figure 5. (A) Cyclic voltammograms of a $0.6 \mathrm{mM}$ acetonitrile solution of complex 3 containing $0.1 \mathrm{M}$ TBA-PF 6 run under the conditions detailed in the Experimental Section. The black trace shows the behavior of the complex on its own, and the red trace shows the behavior in the presence of 50 equiv of tetrabutylammonium nitrite. (B) Overlay of the cyclic voltammograms of a $0.6 \mathrm{mM}$ acetonitrile solution of complex 3 containing $0.1 \mathrm{M}$ TBA- $-\mathrm{PF}_{6}$ in the presence of 50 equiv of tetrabutylammonium nitrite and addition of benzoic acid as indicated: 0 equiv (black line), 1 equiv (red line), 5 equiv (green line), 10 equiv (blue line), and 20 equiv (orange line).
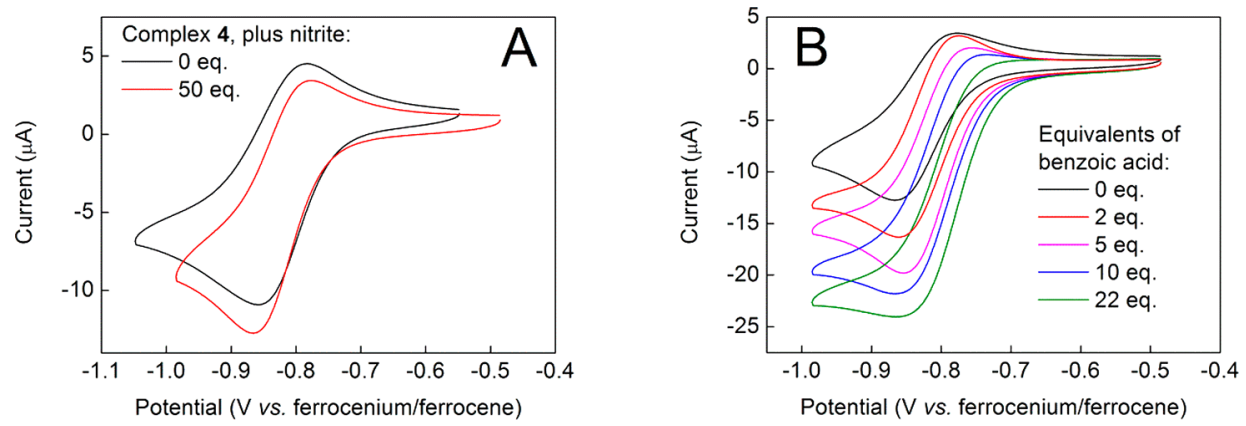

Figure 6. (A) Cyclic voltammograms of a $1 \mathrm{mM}$ acetonitrile solution of complex 4 containing $0.1 \mathrm{MTBA}-\mathrm{PF}_{6}$ run under the conditions detailed in the Experimental Section. The black trace shows the behavior of the complex on its own, and the red trace shows the behavior in the presence of 50 equiv of tetrabutylammonium nitrite. (B) Cyclic voltammograms of a $1 \mathrm{mM}$ acetonitrile solution of complex 4 containing $0.1 \mathrm{M} \mathrm{TBA}^{-\mathrm{PF}} 6$ in the presence of 50 equiv of tetrabutylammonium nitrite and addition of benzoic acid as indicated: 0 equiv (black line), 2 equiv (red line), 5 equiv (purple line), 10 equiv (blue line), and 22 equiv (green line).

pendant carboxylate is protonated and hence not bound to copper.

The infrared spectrum of complex $\left[3-\mathrm{NO}_{2}\right]^{+}$in acetonitrile solution is shown in Figure S6. There is an intense band at $1097 \mathrm{~cm}^{-1}$ which is characteristic of the antisymmetric $\mathrm{N}-\mathrm{O}$ stretch previously observed for nitrite bound to $\mathrm{Cu}(\mathrm{II})$ centers in a $\kappa^{2}$-ONO fashion. ${ }^{30,46}$ This solution-phase IR spectrum is therefore in agreement with the EPR data, which also suggest that nitrite binds to copper through its oxygens in a quasibidentate manner in complex 3. The corresponding symmetrical stretch is expected to come between 1450 and 1400 $\mathrm{cm}^{-1}{ }^{43}$ but this is obscured by signals arising from acetonitrile in the same region. Meanwhile, a band at $1736 \mathrm{~cm}^{-1}$ can be assigned to the $\mathrm{C}=\mathrm{O}$ stretch in the methyl ester. The solidstate infrared spectrum of complex $\left[4-\mathrm{NO}_{2}\right]$ is shown in Figure S7. This spectrum shows strong absorbances at 1362 and 1328 $\mathrm{cm}^{-1}$, which are assigned to the $\nu_{\text {asym }}\left(\mathrm{NO}_{2}\right)$ and $\nu_{\text {sym }}\left(\mathrm{NO}_{2}\right)$ bands of N-bound nitrite, respectively, by comparison with the literature. ${ }^{27,30,43}$ Hence, the IR data are consistent with the EPR spectra and solid-state structures in suggesting that nitrite is predominantly $\mathrm{O}$ bound in complex $\left[3-\mathrm{NO}_{2}\right]^{+}$and predominantly $\mathrm{N}$ bound in complex $\left[4-\mathrm{NO}_{2}\right]$.

Electrocatalysis of Nitrite Reduction. The potential electrocatalytic activity of complexes $\mathbf{3}$ and $\mathbf{4}$ for the reduction of nitrite to $\mathrm{NO}$ was then explored by cyclic voltammetry. Figure 5A (black trace) shows the behavior of complex 3 in acetonitrile containing $0.1 \mathrm{M}$ tetrabutylammonium hexafluor- ophosphate (TBA-PF $)_{6}$. A reversible redox wave is evident at $E_{1 / 2} \approx-0.29 \mathrm{~V}$ (vs ferrocenium/ferrocene), which we assign as the $\mathrm{Cu}(\mathrm{II}) / \mathrm{Cu}(\mathrm{I})$ couple. This wave shifts to significantly more cathodic potentials $\left(E_{1 / 2}=-0.69 \mathrm{~V}\right)$ upon the addition of tetrabutylammonium nitrite (red trace; see also Figure S8 for a comparison over a larger voltage window). The solution also turns green as nitrite is added. Both the color change and the shift in the position of the reversible redox wave are consistent with nitrite binding to the $\mathrm{Cu}$ (II) center and displacing the coordinated acetonitrile found in the crystal structure (Figure $1)$; the replacement of a neutral $\mathrm{CH}_{3} \mathrm{CN}$ ligand by a more electron rich $\mathrm{NO}_{2}^{-}$ligand would be expected to make the reduction of the $\mathrm{Cu}(\mathrm{II})$ center more difficult. There is, however, no catalytic wave that would suggest electroreduction of nitrite mediated by the complex under these conditions.

Figure $5 \mathrm{~B}$ then shows the effect of adding the proton source benzoic acid to a solution of complex 3 containing 50 equiv of tetrabutylammonium nitrite. Hence, it is apparent that, even at 20 equiv of protons added to the solution of complex 3 , the only effect on the wave is a slight cathodic shift to $E_{1 / 2}=-0.71$ $\mathrm{V}$, with no catalytic wave for nitrite reduction evident.

However, the situation changes when the methyl ester on complex 3 is deprotected to give complex 4. In Figure 6A, the $\mathrm{CV}$ of complex 4 in acetonitrile containing $0.1 \mathrm{M}$ tetrabutylammonium hexafluorophosphate is shown (black trace). This presents a reversible redox wave for the $\mathrm{Cu}(\mathrm{II}) /$ $\mathrm{Cu}(\mathrm{I})$ redox couple at $E_{1 / 2}=-0.82 \mathrm{~V}$, the position of which 
changes very little upon addition of nitrite (red trace in Figure $6 \mathrm{~A}$ and see also Figure S9 in the Supporting Information for cyclic voltammograms of $\left[3-\mathrm{NO}_{2}\right]^{+}$and $\left.\left[4-\mathrm{NO}_{2}\right]\right)$. The much more cathodic position of the $\mathrm{Cu}(\mathrm{II}) / \mathrm{Cu}(\mathrm{I})$ redox wave in comparison to that seen in complex 3 is further evidence that the deprotonated carboxylic acid group remains coordinated to the copper center in solution (increasing the effective electron density at the metal and making reduction harder), as seen in the solid state (Figure 3 ) and also as suggested by EPR, mass spectrometry, and $\mathrm{CHN}$ analysis (see the Experimental Section). In contrast to the case for complex 3 , it is therefore very difficult to gauge nitrite binding by observing the shift in the $\mathrm{Cu}(\mathrm{II}) / \mathrm{Cu}(\mathrm{I})$ redox wave for complex 4. However, the color change of the solution from blue to green suggests that nitrite is indeed bound, as do the EPR and crystallographic data. Further evidence for this comes in the shape of the red trace in Figure 6A, which now shows some of the features characteristic of a catalytic wave.

Intrigued by this wave shape, we added benzoic acid to solutions of 4 in the presence of 50 equiv of tetrabutylammonium nitrite, as shown in Figure 6B. A clear trend was apparent, in which adding larger amounts of the proton source gave rise to a more and more pronounced catalytic wave at the potential of the $\mathrm{Cu}(\mathrm{II}) / \mathrm{Cu}(\mathrm{I})$ redox couple. There was also a slight anodic shift in the position of the peak current for this wave with increasing acid concentration.

In order to determine the product(s) of this electrocatalytic activity, we conducted bulk electrolyses in sealed electrochemical cells at the fixed potential $-0.91 \mathrm{~V}$ vs ferrocenium/ ferrocene under a variety of conditions (see the Experimental Section for details). Representative current density vs time curves are shown in Figure 7 for electrolyses using $5 \mathrm{mM}$

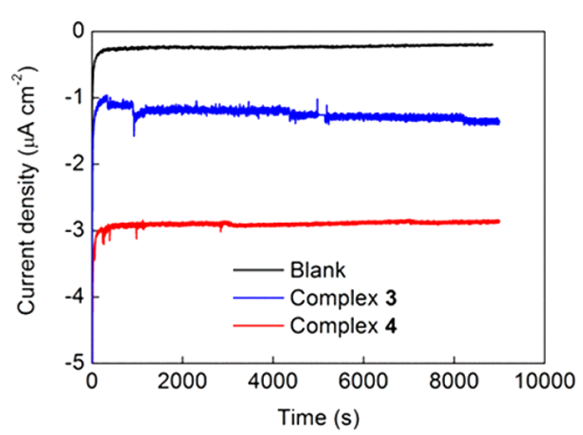

Figure 7. Bulk electrolysis in $0.2 \mathrm{M} \mathrm{TBA}-\mathrm{PF}_{6}$ in acetonitrile of a $7 \mu \mathrm{M}$ solution of complex 3 (blue line) and a $7 \mu \mathrm{M}$ solution of complex 4 (red line) and in the absence of any catalyst (black line) at a fixed potential of $-0.91 \mathrm{~V}$ vs ferrocenium/ferrocene. The working electrode was a glassy-carbon-foil electrode (area $\sim 4.6 \mathrm{~cm}^{2}$ ). An $\mathrm{Ag} / \mathrm{AgNO}_{3}$ pseudo reference electrode and a Pt-wire counter electrode were used. In each case, the electrolyte also contained $5 \mathrm{mM}$ benzoic acid and 5 $\mathrm{mM}$ TBA-NO${ }_{2}$.

benzoic acid, $5 \mathrm{mM}$ TBA- $\mathrm{NO}_{2}$, and complex 3 (blue line), 5 $\mathrm{mM}$ benzoic acid, $5 \mathrm{mM}$ TBA- $\mathrm{NO}_{2}$, and complex 4 (red line), and a control containing just $5 \mathrm{mM}$ benzoic acid and $5 \mathrm{mM}$ TBA- $\mathrm{NO}_{2}$ (black line). Hence it is apparent that considerably more current flows when complex $\mathbf{4}$ is employed in comparison to when complex 3 is used or in comparison to the background reaction. In order to determine if any $\mathrm{NO}$ was produced during these bulk electrolyses, we used the known NO complexation agent cobalt(II) meso-tetraphenylporphyrin (Co-TPP), ${ }^{90-93}$ which undergoes a highly characteristic shift in the position of its visible absorption band $\left(\lambda_{\max } \sim 530 \mathrm{~nm}\right)$ upon NO binding. $^{29,94}$ A calibration curve (Figures S10 and S11) was constructed, which allowed the amount of NO in the reaction vessel headspace to be determined on the basis of the position of the Co-TPP absorption band (see the Experimental Section for details). By assessing the shifts produced in the Co-TPP absorption band in bulk electrolyses that passed various amounts of charge, a Faradaic yield for the production of $\mathrm{NO}$ by complex 4 of $97.3 \pm 3.6 \%$ was obtained.

In an extended-run bulk electrolysis with complex 4 (Figure S12), $0.225 \mathrm{C}$ of charge were passed for the reduction of nitrite to NO over $22000 \mathrm{~s}$, without any apparent diminution of the current density. Given a concentration of catalyst of $7 \mu \mathrm{M}$ in 15 $\mathrm{mL}$ of solution, this corresponds to around 22 turnovers of the catalyst, thus proving that complex $\mathbf{4}$ is functioning as a genuine catalyst for this reaction.

Inspection of Figure 7 suggests that current appreciably above the background level is also observed with complex 3 in the presence of benzoic acid and TBA- $\mathrm{NO}_{2}$. Moreover, CoTPP-based colorimetric NO determination assays revealed that this current was associated with NO formation (Faradaic yield $88.2 \pm 7.3 \%)$. Given the apparent absence of electrocatalytic activity evident in Figure 5, this was initially surprising to us. We therefore conducted further cyclic voltammetry experiments with complex 3 in the presence of benzoic acid and TBA- $\mathrm{NO}_{2}$ at the slower scan rate of $10 \mathrm{mV} \mathrm{s}^{-1}$, as shown in Figure S13. This indicated that a catalytic wave is evident when the scan rate is slowed. In combination with the abovebackground currents observed by bulk electrolysis (and the associated detection of NO), this suggests that complex 3 is indeed competent for nitrite reduction electrocatalysis but that the catalysis with complex 3 is less effective than it is with complex 4. Indeed, in an extended-run bulk electrolysis, complex 3 could be induced to turn over 10 times in a $17000 \mathrm{~s}$ time period (see Figure S12).

To further confirm the production of $\mathrm{NO}$ during bulk electrolysis, NO release profiles were obtained using a Sievers NOA 280i chemiluminescence nitric oxide analyzer (see the Experimental Section). Figure 8 shows one such experiment with complex 4 in which a bulk electrolysis was performed for 1 $\mathrm{h}$ at a fixed potential of $-0.91 \mathrm{~V}$ vs ferrocenium/ferrocene in a sealed cell (panel A), after which time the contents of the headspace were flushed into the detector of the Sievers instrument using a stream of nitrogen. The main panel in Figure $8 \mathrm{~B}$ then shows the total (cumulative) amount of $\mathrm{NO}$ measured by the detector after termination of the electrolysis, while the inset shows the instantaneous level of NO detected. On the basis of this instantaneous data, one can conclude that, after about $300 \mathrm{~s}$, the level of NO detected has decayed back to basal levels. The slope of the graph in the main panel after $300 \mathrm{~s}$ therefore allows the rate of background NO production due to spontaneous processes to be calculated. Subtracting this value from the overall amount of NO produced gives a Faradaic yield for NO production by complex 4 using this method of $100 \pm$ $1 \%$, in good agreement with the values obtained by colorimetric tests. As expected, an electrolysis under the same conditions but in the absence of any catalyst produces significantly less NO (see Figure S14).

The above tests serve to establish that both complexes 3 and 4 are competent for electrocatalytic nitrite reduction to NO with essentially full Faradaic efficiency but that complex 4 appears to be the more effective of the two. In order to gain 

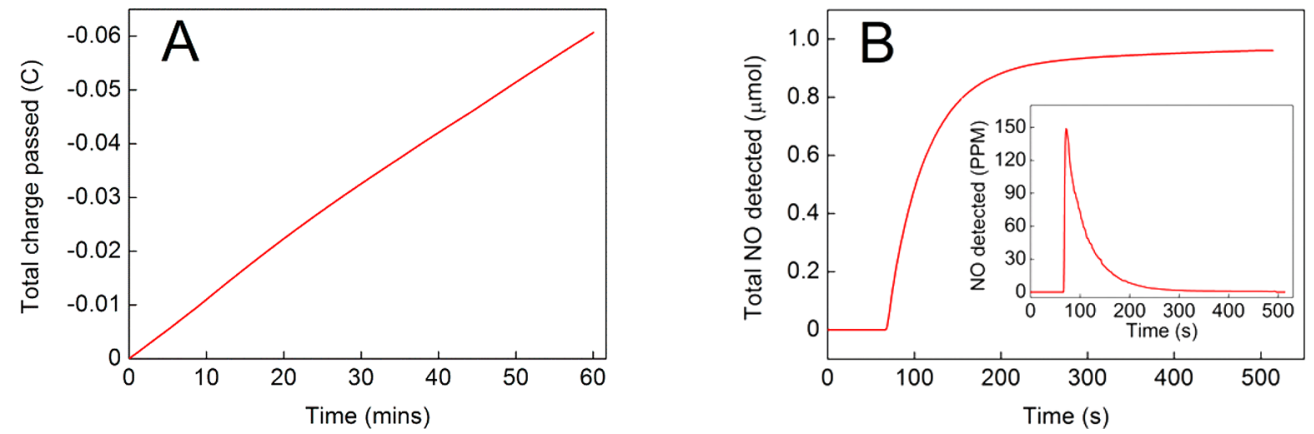

Figure 8. (A) Charge vs time curve for the bulk electrolysis of complex 4 at a fixed potential of $-0.91 \mathrm{~V}$ vs ferrocenium/ferrocene in acetonitrile/ 0.2 $\mathrm{M}$ TBA- $-\mathrm{PF}_{6}$ as per the conditions detailed in the Experimental Section. (B) Total NO measured upon flushing the contents of the cell headspace into the NO detector after termination of electrolysis. The inset shows instantaneous NO detection.

insight into these apparent differences in catalytic activity, further electrochemical investigations were undertaken.

First, Tafel analysis of 3 and 4 in $0.1 \mathrm{M} \mathrm{TBA}-\mathrm{PF}_{6} /$ acetonitrile in the presence of 30 equiv of both TBA- $\mathrm{NO}_{2}$ and benzoic acid was found to give slopes of 138 and $128 \mathrm{mV} \mathrm{decade}{ }^{-1}$, respectively, if a transfer coefficient of 0.5 was assumed (Figure S15). These are close to the theoretical value for a rate-limiting one-electron process $\left(120 \mathrm{mV}\right.$ decade $\left.^{-1}\right)$, in agreement with a reaction such as that given in eq 1 for the one-electron reduction of nitrite to NO.

Next, we investigated the kinetics of the nitrite reduction reaction by cyclic voltammetry. Hence the peak current for electrocatalytic nitrite reduction by both complex 3 and complex 4 was measured as a function of nitrite concentration in the presence of a large excess (300 equiv relative to the catalyst complexes) of benzoic acid at a scan rate of $10 \mathrm{mV} \mathrm{s}^{-1}$ (at which scan rate there is evidence of an electrocatalytic wave with both complexes; see above). As the Faradaic yield for NO production is essentially unity, and as the reduction of nitrite to $\mathrm{NO}$ is a one-electron process, these current densities can be converted to a rate of nitric oxide production per unit area of electrode $\left(V_{[\mathrm{NO}]}\right)$ by dividing the current density by Faraday's constant. These data (Figures S16-S18) can then be fitted to Michaelis-Menten-type kinetics as per eq 2

$$
V_{[\mathrm{NO}]}=V_{\max }\left[\mathrm{NO}_{2}^{-}\right] /\left(K_{\mathrm{M}}+\left[\mathrm{NO}_{2}^{-}\right]\right)
$$

which allows the maximum rate of reaction $\left(V_{\max }\right)$ for complex 4 to be estimated as being $14.7 \pm 1.5 \mathrm{nmol} \mathrm{s}^{-1} \mathrm{~cm}^{-2}$, with a Michaelis constant $\left(K_{\mathrm{M}}\right)$ of $11 \pm 3 \mathrm{mM}$ (see Figure 9). Rates of NO formation are shown as negative in Figure 9, as these derive from cathodic (reductive) currents in the CVs. The value of $V_{\max }$ can be deconvoluted to yield the Michaelis-Menten $k_{\text {cat }}$ (the turnover frequency) by dividing $V_{\max }$ by the concentration of catalyst molecules. In our case, this concentration corresponds to the number of catalyst molecules participating in the electrochemical reaction, which (given that the reaction medium is not stirred in these CV measurements) can be determined by integrating the charge passed in the reversible $\mathrm{Cu}(\mathrm{II}) / \mathrm{Cu}(\mathrm{I})$ redox wave in the absence of substrate. When this integration is performed, an electrochemically active surface concentration of catalyst molecules of $1.1 \times 10^{-9} \mathrm{~mol} \mathrm{~cm}^{-2}$ is obtained, which in turn gives a value for $k_{\text {cat }}$ (the turnover frequency) for complex 4 of $13.4 \pm 1.4 \mathrm{~s}^{-1}$. From this value, the catalytic efficiency of the catalyst can be expressed by the ratio $k_{\text {cat }} / K_{\mathrm{M}}$, which gives a value of around $1200 \mathrm{M}^{-1} \mathrm{~s}^{-1}$. These values can be compared to those previously reported by Orain and co-workers and Yamaguchi and co-workers for $\mathrm{Cu}$-TMPA

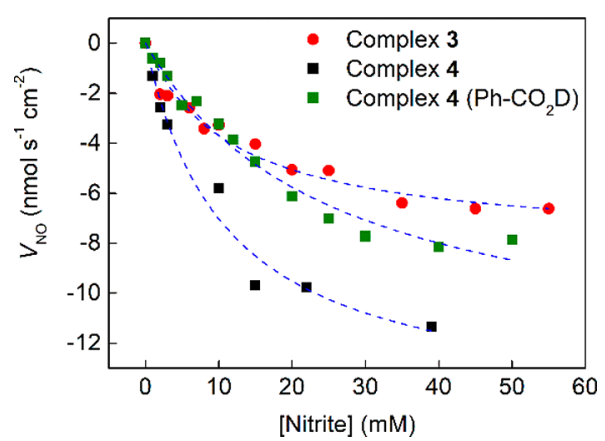

Figure 9. Dependence of the rate of electrochemical NO generation on $\left[\mathrm{NO}_{2}^{-}\right]$for complexes 3 (red circles) and 4 (black squares) in the presence of 300 equiv of benzoic acid $\left(\mathrm{Ph}-\mathrm{CO}_{2} \mathrm{H}\right)$ in acetonitrile/0.2 $\mathrm{M}$ TBA- $-\mathrm{PF}_{6}$ as per the conditions detailed in the Experimental Section. The green squares show analogous data for complex 4 but in deuterated acetonitrile/0.2 M TBA-PF ${ }_{6}$ in the presence of 300 equiv of deuterated benzoic acid $\left(\mathrm{Ph}-\mathrm{CO}_{2} \mathrm{D}\right)$. The blue dashed lines show fits to the Michaelis-Menten equation.

complexes without any pendant acid/base units immobilized on the surface of an electrode and performing the reduction of nitrite to NO in aqueous solution. ${ }^{47,50}$ Hence, the best metrics achieved by Orain and co-workers were $k_{\text {cat }}=1.39 \mathrm{~s}^{-1}$ with $K_{\mathrm{M}}$ $=70 \mathrm{mM}$ (giving $k_{\text {cat }} / K_{\mathrm{M}}=17.4 \mathrm{M}^{-1} \mathrm{~s}^{-1}$ ), while Yamaguchi and co-workers reported $k_{\text {cat }}=0.11 \mathrm{~s}^{-1}$ with $K_{\mathrm{M}}=15.8 \mathrm{mM}$ (giving $k_{\text {cat }} / K_{\mathrm{M}}=7.0 \mathrm{M}^{-1} \mathrm{~s}^{-1}$ ). On this basis, our system is the most effective small molecule $\mathrm{Cu}$-based platform for electrocatalysis of $\mathrm{NO}_{2}^{-}$reduction to $\mathrm{NO}$ yet reported. For comparison, the CuNIR enzyme from Alcaligenes faecalis has been estimated to have a turnover frequency of around 2000 $\mathrm{s}^{-1}$ and a $K_{\mathrm{M}}$ of around $100 \mu \mathrm{M}$, giving $k_{\mathrm{cat}} / K_{\mathrm{M}} \approx 2 \times 10^{7} \mathrm{M}^{-1}$ $\mathrm{s}^{-1} \cdot 95$

To discriminate between the effects of the pendant acid/base group and the change in solvent and reaction conditions on this apparent improvement in catalytic efficiency relative to the previous studies with TMPA-based $\mathrm{Cu}$ complexes, we also performed a similar Michaelis-Menten analysis on complex 3 (which lacks any the pendant acid/base groups) under analogous conditions (Figure 9 and Figure S18). The resulting Michaelis-Menten plot allowed the maximum rate of reaction $\left(V_{\max }\right)$ to be estimated as $8.0 \pm 0.5 \mathrm{nmol} \mathrm{s} \mathrm{cm}^{-2}$, with a Michaelis constant $\left(K_{\mathrm{M}}\right)$ of $12 \pm 2 \mathrm{mM}$. Taking the electrochemically active surface concentration of catalyst molecules to be $1.1 \times 10^{-9} \mathrm{~mol} \mathrm{~cm}{ }^{-2}$, the value of $k_{\text {cat }}$ is then $7.3 \pm 0.5 \mathrm{~s}^{-1}$, giving $k_{\mathrm{cat}} / K_{\mathrm{M}} \approx 600 \mathrm{M}^{-1} \mathrm{~s}^{-1}$. Hence, there is a demonstrable enhancement in the catalytic performance of 
Scheme 3. Proposed Pathway of the Electrocatalytic Reduction of $\mathrm{NO}_{2}^{-}$to $\mathrm{NO}$ and $\mathrm{H}_{2} \mathrm{O}$ using the $\left[4-\mathrm{NCCH}_{3}\right]^{+}$Precatalyst, Showing Optimized Structures ${ }^{a}$

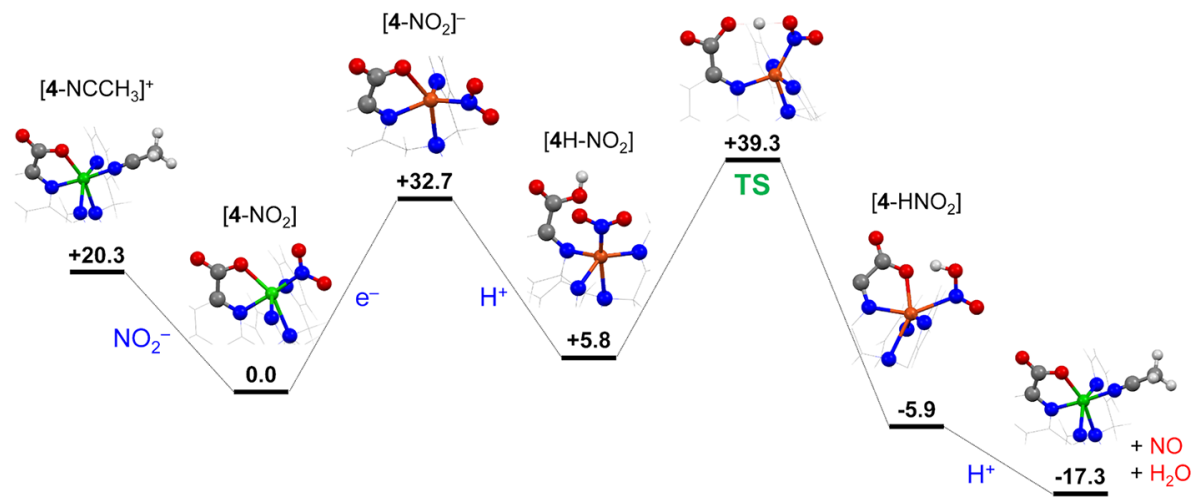

${ }^{a}$ Color scheme: $\mathrm{Cu}(\mathrm{II})$, green; $\mathrm{Cu}(\mathrm{I})$, bronze; O, red; N, blue; $\mathrm{C}$, pewter; $\mathrm{H}$, white. Relative energies at the PBE0/ZORA/def2-TZVP+COSMO$\mathrm{RS}\left[\mathrm{CH}_{3} \mathrm{CN}\right]$ level are in $\mathrm{kcal} \mathrm{mol}^{-1}$.

complex 4 in comparison to complex 3 over and above that attributable to the change in solvent medium relative to the previous studies. 47,50

The nature of the proton-coupled electron transfer event occurring during nitrite reduction with complex 4 was then probed by comparing the kinetics in a protic environment with those observed under deuterated conditions. Hence, the solvent medium was switched to $\mathrm{CD}_{3} \mathrm{CN}$ and a deuterated benzoic acid source $\left(\mathrm{Ph}-\mathrm{CO}_{2} \mathrm{D}\right)$ was used. Figure 9 (green squares) shows the results of this deuteration. $V_{\max }$ remains largely unaltered with respect to protic conditions, at $13.1 \pm 1.1 \mathrm{nmol} \mathrm{s}^{-1} \mathrm{~cm}^{-2}$ (giving $k_{\text {cat }}=11.9 \pm 1.0 \mathrm{~s}^{-1}$ ). However, $K_{\mathrm{M}}$ increases significantly to $25 \pm 4 \mathrm{mM}$, suggesting that higher concentrations of substrate are required to reach this maximum turnover frequency. This in turn gives a value for the catalytic efficiency of complex 4 under deuterated conditions of around $470 \mathrm{M}^{-1} \mathrm{~s}^{-1}$, implying a significant kinetic isotope effect of $\sim 2.5$. The fact that such a pronounced effect can be seen upon moving to deuterated solvents suggests that the proton and electron transfers are concerted. ${ }^{96}$

Calculations. On the basis of the experimental observations derived from spectroscopic and electrochemical data, a mechanism for the catalytic reduction of nitrite to nitric oxide was developed using DFT calculations. Optimizations were performed at the BP86 level of theory using the def2-SVP basis set for all atoms and acetonitrile as the solvent continuum. Single-point calculations were performed on the optimized coordinates at the PBE0 level of theory with triple- $\zeta$ basis sets.

In these simulations, we found that nitrite readily displaces a coordinated solvent molecule $\left(\mathrm{H}_{2} \mathrm{O}\right.$ or $\left.\mathrm{CH}_{3} \mathrm{CN}\right)$ from complexes 3 and 4 to give $\left[3-\mathrm{NO}_{2}\right]^{+}$and $\left[4-\mathrm{NO}_{2}\right]$. The coordination mode of the nitrite ligand in $\left[4-\mathrm{NO}_{2}\right]$ favors the $\mathrm{N}$-bound (nitro) linkage isomer by $2.9 \mathrm{kcal} \mathrm{mol}^{-1}$ over that of the nitrito (O-bound) variant. Although this is very close to the limit of energies distinguishable by DFT, it does match the solid-state structure (Figure 3) and the major solution-phase species suggested by EPR (Figure 4). Additionally, no optimized complex retained a chelating $\kappa^{2}$-ONO ligand when it was combined with 4 . For 3 , the absence of the pendant acid/ base group gave isoenergetic complexes with nitro or chelating nitrito ligands ( $1.4 \mathrm{kcal} \mathrm{mol}^{-1}$ in favor of the latter). The latter is proposed to be the complex that provides the largest contribution to the EPR spectrum of $\left[3-\mathrm{NO}_{2}\right]^{+}$on account of the sizable $g$ shift in comparison with $\left[4-\mathrm{NO}_{2}\right]$ (see EPR discussion above and Figure S4). These isomers were $5.6 \mathrm{kcal}$ $\mathrm{mol}^{-1}$ more favorable energetically than the complex with a monodentate nitrito ligand.

Having established the most likely entry point into the catalytic cycle as being $\left[4-\mathrm{NO}_{2}\right]$, further computational analysis (Scheme 3) reveals that protonation of $\left[4-\mathrm{NO}_{2}\right]$ to give $[4 \mathrm{H}$ $\left.\mathrm{NO}_{2}\right]^{+}$would afford a $17.2 \mathrm{kcal} \mathrm{mol}^{-1}$ increase in stability, but (as discussed above in relation to the EPR data) there is no evidence to support protonation of the carboxylate group in [4$\left.\mathrm{NO}_{2}\right]$ in the presence of excess benzoic acid. On the other hand, reduction of $\left[4-\mathrm{NO}_{2}\right]$ by one electron (to give the $\mathrm{Cu}(\mathrm{I}$ ) species $\left[4-\mathrm{NO}_{2}\right]^{-}$) leads to a decrease in stability of $32.7 \mathrm{kcal}$ $\mathrm{mol}^{-1}$. This is unsurprising, as six-coordinate species are not favored by $\mathrm{Cu}(\mathrm{I})$. However, subsequent protonation of the carboxylate in $\left[4-\mathrm{NO}_{2}\right]^{-}$to give $\left[4 \mathrm{H}-\mathrm{NO}_{2}\right]$ (in which the carboxylate unit is no longer coordinated to copper) affords a $26.9 \mathrm{kcal} \mathrm{mol}^{-1}$ increase in stability relative to $\left[4-\mathrm{NO}_{2}\right]^{-}$. This DFT-modeled PCET is therefore consistent with the experimental observation of concerted proton and electron transfer, in which the reduction of the $\mathrm{Cu}$ (II) complex is concomitant with the release and protonation of the carboxylate, leading directly from $\left[4-\mathrm{NO}_{2}\right]$ to $\left[4 \mathrm{H}-\mathrm{NO}_{2}\right]$ and avoiding the high energy $\left[4-\mathrm{NO}_{2}\right]^{-}$intermediate.

Computational optimization of $\left[4 \mathrm{H}-\mathrm{NO}_{2}\right]$ then leads spontaneously to a structure where the carboxylate proton has migrated to the adjacent nitro ligand to give a coordinated nitrous acid group, $\left[4-\mathrm{HNO}_{2}\right]$ (Scheme 3 ). This underscores the key role played by the proton-relaying group in nitrite reduction, as the in silico process follows a path analogous to that observed experimentally. This is not the case for the nitrito isomers of this $\mathrm{Cu}(\mathrm{I})$ complex, which are less stable than the nitro isomer. This further corroborates our assignment of the nitro isomer as the catalytically competent species in complex 4. Meanwhile, complex 3 is found to be a less effective electrocatalyst for this process than complex 4 , which can be attributed both to its lack of any proton-relaying units and to the different nature of the dominant nitrite coordination mode in complex 3 (i.e., predominantly through oxygen), which will also have an effect on the $\mathrm{N}-\mathrm{O}$ bond cleavage pathway that is followed with this complex.

Following the PCET to generate $\left[4 \mathrm{H}-\mathrm{NO}_{2}\right]$, the proton undergoes intramolecular proton transfer from the pendant carboxylic group to the bound nitrite, to give $\left[4-\mathrm{HNO}_{2}\right]$. This process was modeled by creating fixed-structure complexes 
where the proton was incrementally shifted from the carboxylate to the adjacent nitrite ligand. A transition state ("TS" in Scheme 3) where the $\mathrm{H}^{+}$resides midway between these donor/acceptor ligands presents a $33.5 \mathrm{kcal} \mathrm{mol}^{-1}$ barrier in this process. Plotting the same reaction pathway with a sequence of $\mathrm{Cu}(\mathrm{II})$ species (i.e., without the electron transfer process) presents a demanding $50.7 \mathrm{kcal} \mathrm{mol}^{-1}$ barrier to the intramolecular proton transfer step. Furthermore, optimization of a $\mathrm{Cu}(\mathrm{II})$ species with a coordinated nitrous acid ligand, [4$\left.\mathrm{HNO}_{2}\right]^{+}$, sees the proton migrate back toward the pendant carboxylate. In Scheme 3, there are then further energy gains leading to a $\mathrm{Cu}(\mathrm{I})$ center with an $\mathrm{N}$-coordinated nitrous acid and finally an electron transfer from the $\mathrm{Cu}(\mathrm{I})$ to the nitrous acid, giving the reaction products nitric oxide and water and regenerating the precatalyst.

\section{CONCLUSIONS}

In summary, we have developed two new catalysts ( 3 and 4 ) for the selective electroreduction of nitrite to NO that function with essentially full Faradaic efficiency for NO production, as indicated by NO-trapping and chemiluminescence tests. In comparison to literature reports for electrocatalytic nitrite reduction with $\mathrm{Cu}$ complexes, $\mathbf{3}$ and $\mathbf{4}$ are the most efficient catalysts for this transformation yet reported by over 1 order of magnitude. Moreover, we have shown that incorporation of a proton-relaying moiety into the secondary coordination sphere of one of these complexes (4) enhances the electrocatalytic nitrite reduction activity displayed by this complex by a factor of 2 in comparison to the analogous complex that lacks this functionality (complex 3 ). Using DFT calculations, the possible role of the pendant carboxylate unit in facilitating protonation of the bound nitrite can be discerned. This study therefore constitutes the first report in which the role of proton-coupled electron transfer in the reduction of nitrite to NO with synthetic molecular catalysts has been addressed. Our results serve to highlight the central role of proton-coupled electron transfer in the reduction of nitrite to NO (and in the activation of small molecules in general) and could have important implications for the development of new catalysts for the selective interconversions of the nitrogen oxides and other substrates.

\section{EXPERIMENTAL SECTION}

General Experimental Remarks. Tetrabutylammonium hexafluorophosphate (TBA-PF $6>98 \%$ ) was supplied by TCI. Bis(2-pyridylmethyl)amine (97\%), benzoic acid (99.5\%), $\mathrm{Cu}\left(\mathrm{ClO}_{4}\right)_{2} \cdot 6 \mathrm{H}_{2} \mathrm{O}(98 \%)$, sodium nitrite (minimum 99.0\%), and tetrabutylammonium nitrite were purchased from SigmaAldrich. All chemical reagents and solvents were used as purchased. Electronic spectra were collected in quartz cuvettes on a JASCO V-670 spectrophotometer. Solution-phase IR spectra were collected with a Shimadzu FTIR-8400S instrument, and solid-state IR spectra were obtained on a Thermo Scientific Nicolet iS5 apparatus. X-band EPR spectra were recorded on a Bruker ELEXSYS E500 spectrometer, and simulations were performed with Bruker's Xsophe software package. ${ }^{97}$ All ${ }^{1} \mathrm{H}$ and ${ }^{13} \mathrm{C}$ NMR spectra were recorded on a Bruker AV 400 instrument, at a constant temperature of $300 \mathrm{~K}$. Chemical shifts are reported in parts per million from low to high field. Coupling constants $(J)$ are reported in hertz $(\mathrm{Hz})$. Standard abbreviations indicating multiplicity are used as follows: $\mathrm{m}=$ multiplet, $\mathrm{t}=$ triplet, $\mathrm{d}=$ doublet, $\mathrm{s}=$ singlet.
$\mathrm{CHN}$ analyses were collected by the services facility at the School of Chemistry, University of Glasgow, as were LM-MS mass spectra (ESI, positive mode, Bruker micrOTOF-Q machine).

Compound 1. To a solution of 6-chloromethylpyridine-2carboxylic acid methyl ester ${ }^{75}(270 \mathrm{mg}, 1.45 \mathrm{mmol}, 1$ equiv) in $\mathrm{CH}_{3} \mathrm{CN}(14 \mathrm{~mL})$ was added $848 \mathrm{mg}$ of $\mathrm{Na}_{2} \mathrm{CO}_{3}$ ( $8 \mathrm{mmol}, 5.5$ equiv), giving a yellowish suspension. To this mixture was added a solution of bis(2-pyridylmethyl)amine (319 mg, 1.6 mmol, 1.1 equiv) in $\mathrm{CH}_{3} \mathrm{CN}(8 \mathrm{~mL})$, and the resulting mixture was heated to reflux for $24 \mathrm{~h}$. No change of color was seen when the amine was added, but as the reaction mixture was heated, it turned orange. After $24 \mathrm{~h}$ reflux, the mixture was cooled to room temperature and then filtered to remove the $\mathrm{Na}_{2} \mathrm{CO}_{3}$. The filtrate was then concentrated in vacuo, affording crude compound $\mathbf{1}$ as a tan solid. This solid was then triturated with ethyl acetate/hexane (4/1), yielding an off-white solid and an orange liquid. Isolation of the solid and a further round of trituration in ethyl acetate/hexane (4/1) then yielded pure compound 1 (380 mg, $1.09 \mathrm{mmol}, 75 \%) .{ }^{1} \mathrm{H}$ NMR (MeOD, $400 \mathrm{MHz}): \delta 8.44-8.42\left(\mathrm{~m}, 2 \mathrm{H}, \mathrm{H}_{\mathrm{a}}\right), 7.98\left(\mathrm{dd}, J_{1}=8, J_{2}=1\right.$, $\left.1 \mathrm{H}, \mathrm{H}_{\mathrm{g} \text { or }} \mathrm{H}_{\mathrm{i}}\right), 7.92\left(\mathrm{t}, J=8,1 \mathrm{H}, \mathrm{H}_{\mathrm{h}}\right), 7.86\left(\mathrm{dd}, J_{1}=8, J_{2}=1\right.$, $\left.1 \mathrm{H}, \mathrm{H}_{\mathrm{g} \text { or }} \mathrm{H}_{\mathrm{i}}\right), 7.78\left(\mathrm{dt}, J_{1}=8, J_{2}=2,2 \mathrm{H}, \mathrm{H}_{\mathrm{b} \text { or }} \mathrm{H}_{\mathrm{c}}\right), 7.68(\mathrm{~d}, J=$ $\left.8,2 \mathrm{H}, \mathrm{H}_{\mathrm{d}}\right), 7.29-7.24\left(\mathrm{~m}, 2 \mathrm{H}, \mathrm{H}_{\mathrm{b} \text { or }} \mathrm{H}_{\mathrm{c}}\right), 3.96\left(\mathrm{~s}, 3 \mathrm{H}, \mathrm{H}_{\mathrm{j}}\right), 3.94$ $\left(\mathrm{s}, 2 \mathrm{H}, \mathrm{H}_{\mathrm{f}}\right), 3.88\left(\mathrm{~s}, 4 \mathrm{H}, \mathrm{H}_{\mathrm{e}}\right)$. Letter codes correspond to those shown on the ${ }^{1} \mathrm{H}$ NMR spectrum of this compound in Figure $\mathrm{S} 1$ in the Supporting Information. ${ }^{13} \mathrm{C}$ NMR (MeOD, 400 $\mathrm{MHz}): \delta 166.7,161.0,159.8,149.5,148.0,139.1,138.5,127.9$, 124.8, 124.6, 123.7, 61.1, 60.6, 53.0. ESI-LMMS (methanol): $m / z 371.1464[\mathrm{M}+\mathrm{Na}]^{+}$(calcd for $\mathrm{C}_{20} \mathrm{H}_{20} \mathrm{~N}_{4} \mathrm{NaO}_{2} 371.1484$ ).

Compound 2. A $498 \mathrm{mg}(1.43 \mathrm{mmol})$ portion of compound 1 was dissolved in $5 \mathrm{~mL}$ of ethanol with the aid of ultrasonication. To this solution was then added $20 \mathrm{~mL}$ of $0.5 \mathrm{M} \mathrm{NaOH}$, and the mixture heated to reflux for $20 \mathrm{~h}$. After this time, the reaction mixture was cooled to room temperature and concentrated in vacuo to remove the ethanol. The resulting reaction mixture was then acidified to $\mathrm{pH} 4$ with aqueous $\mathrm{HCl}$ and then extracted with $\mathrm{CHCl}_{3}(2 \times 100 \mathrm{~mL})$. The combined organic extracts were then dried over $\mathrm{MgSO}_{4}$ and concentrated under reduced pressure to yield compound $\mathbf{2}$ as a yellow oil (200 mg, $0.598 \mathrm{mmol}, 42 \%$ ). The compound gave spectra in agreement with those previously reported for this compound. ${ }^{76}$

Complex $3-\mathrm{H}_{2}$ O. A $95 \mathrm{mg}(0.273 \mathrm{mmol}, 1$ equiv) portion of compound 1 was dissolved in $3.5 \mathrm{~mL}$ of ethanol, giving a bright yellow solution. This solution was then added (with stirring) to a solution of $104 \mathrm{mg}(0.273 \mathrm{mmol}, 1$ equiv) of $\mathrm{Cu}\left(\mathrm{ClO}_{4}\right)_{2} \cdot 6 \mathrm{H}_{2} \mathrm{O}$ in $3.5 \mathrm{~mL}$ of $\mathrm{EtOH}$, leading to the immediate formation of a dark blue precipitate. The reaction mixture was stirred for a further $10 \mathrm{~min}$, after which it was filtered, yielding complex $3-\mathrm{H}_{2} \mathrm{O}$ as a dark blue solid $(160 \mathrm{mg}, 0.254 \mathrm{mmol}$, 93\%). Anal. Calcd for $\mathrm{C}_{20} \mathrm{H}_{22} \mathrm{Cl}_{2} \mathrm{CuN}_{4} \mathrm{O}_{11}$ : C, 38.20; H, 3.53; $\mathrm{N}$, 8.91. Found: C, 38.13; H, 3.16; N, 8.89. ESI-LMMS (methanol): $m / z 411.0517\left[\mathrm{M}-\mathrm{H}_{2} \mathrm{O}\right]^{+}$(calcd for $\mathrm{C}_{20} \mathrm{H}_{20} \mathrm{CuN}_{4} \mathrm{O}_{2} 411.0882$ ).

Complex $4-\mathrm{H}_{2} \mathrm{O}$. An $82 \mathrm{mg}$ ( $0.24 \mathrm{mmol}, 1.1$ equiv) portion of $\mathrm{Cu}\left(\mathrm{ClO}_{4}\right)_{2} \cdot 6 \mathrm{H}_{2} \mathrm{O}$ was dissolved in $3 \mathrm{~mL}$ of $\mathrm{EtOH}$, giving a light blue solution. Meanwhile, $74 \mathrm{mg}(0.22 \mathrm{mmol}, 1$ equiv) of compound 2 was dissolved in $3 \mathrm{~mL}$ of ethanol, giving a dark yellow-orange solution, and this solution was then added to the blue copper solution. A greenish blue precipitate immediately formed, which was filtered off and dried, giving complex 4- $\mathrm{H}_{2} \mathrm{O}$ (0.074 g, $0.144 \mathrm{mmol}, 60 \%$ ). Anal. Calcd for $\mathrm{C}_{19} \mathrm{H}_{19} \mathrm{ClCuN}_{4} \mathrm{O}_{7}$ : C, 44.37; H, 3.72; N, 10.89. Found: C, 44.68; H, 3.37; N, 10.73. 
MS-FAB/NOVA (low resolution): $m / z 396\left([\mathrm{M}]^{+}-\mathrm{H}_{2} \mathrm{O}\right)$. ESI-LMMS (methanol): $m / z 396.0624\left([\mathrm{M}]^{+}-\mathrm{H}_{2} \mathrm{O}\right)($ calcd for $\mathrm{C}_{19} \mathrm{H}_{17} \mathrm{CuN}_{4} \mathrm{O}_{2}$ 396.0648).

Crystallography. Crystallographic data were collected at the University of Glasgow on a Bruker APEX-II CCD diffractometer for $\left[3-\mathrm{CH}_{3} \mathrm{CN}\right]\left(\mathrm{ClO}_{4}\right)_{2}$ and using a Bruker D8Venture with PhotonII detector and dual $\mathrm{I} \mu \mathrm{s} 3.0$ microsource for $\left[4-\mathrm{NO}_{2}\right]$. For $\left[3-\mathrm{CH}_{3} \mathrm{CN}\right]^{2+}$, a blue, block-shaped crystal of dimensions $0.42 \times 0.4 \times 0.31 \mathrm{~mm}$ was used for singlecrystal X-ray diffraction data collection. $\mathrm{C}_{22} \mathrm{H}_{23} \mathrm{CuN}_{5} \mathrm{O}_{2} \cdot 2 \mathrm{ClO}_{4}$ crystallized in the triclinic space group $P \overline{1}$ (space group No. 2), with unit cell dimensions $a=8.4706(7) \AA$, $b=8.8319(8) \AA$, $c=$ 17.982(2) $\AA, \alpha=95.471(2)^{\circ}, \beta=99.637(2)^{\circ}, \gamma=102.415(2)^{\circ}$, and $V=1283.2(2) \AA^{3}$ at $T=100 \mathrm{~K}$. A total of 15864 reflections were measured by $\omega$ scans, 5798 of which were independent with $R_{\text {int }}=0.068, \theta_{\max }=27.4^{\circ}$, and $\theta_{\min }=1.2^{\circ}$ using Mo $\mathrm{K} \alpha$ radiation $(\lambda=0.71073 \AA)$. The structure was solved using Superflip ${ }^{98-100}$ and refined using SHELXL ${ }^{101}$ within OLEX2, ${ }^{102}$ which was also used for molecular graphics and for preparation of material for publication. CCDC entry 1588602 contains the supplementary crystallographic data for this compound.

For $\left[4-\mathrm{NO}_{2}\right]$, a green block-shaped crystal of dimensions $0.39 \times 0.33 \times 0.16 \mathrm{~mm}$ was used for single-crystal X-ray diffraction data collection. $\mathrm{C}_{19} \mathrm{H}_{17} \mathrm{CuN}_{5} \mathrm{O}_{4} \cdot 0.5 \mathrm{C}_{2} \mathrm{H}_{3} \mathrm{~N}$ crystallized in the orthorhombic space group $\mathrm{Pbcn}$, with unit cell dimensions $a=14.817(8) \AA, b=19.01$ (1) $\AA, c=15.569$ (9) $\AA$, and $V=4386(4) \AA^{3}$ at $T=298 \mathrm{~K}$. A total of 8296 reflections were measured by $\omega$ scans, 5403 of which were independent with $R_{\text {int }}=0.037, \theta_{\max }=28.3^{\circ}$, and $\theta_{\text {min }}=2.2^{\circ}$ using Mo K $\alpha$ radiation $(\lambda=0.71073 \AA)$. The structure was solved using $\mathrm{XT}^{103}$ and refined using SHELXL ${ }^{104}$ within OLEX2, which was again used for molecular graphics and for preparation of material for publication. The nitrite nitrogen atom is wellordered; however, the oxygen atoms show disorder and were modeled as follows: O1N was modeled as fully occupied and common to both partially occupied orientations of $\mathrm{O} 2 \mathrm{~N}$ and $\mathrm{O} 3 \mathrm{~N}$, each of which was modeled as 0.5 -occupied. All oxygen atoms show large atomic displacements. Distance similarity restraints were applied to the $\mathrm{N} 1 \mathrm{~N}-\mathrm{O} 2 \mathrm{~N}$ and $\mathrm{N} 1 \mathrm{~N}-\mathrm{O} 3 \mathrm{~N}$ distances. CCDC entry 1588603 contains the supplementary crystallographic data for this compound. More details on the crystallographic data and its collection can be found in the Supporting Information.

Electrochemical Methods. Electrochemical studies were performed in a three-electrode configuration using $\mathrm{CH}$ Instruments $\mathrm{CHI} 760 \mathrm{D}$ potentiostats. For cyclic voltammetry, a $\mathrm{Pt}$ wire was used as the counter electrode, along with an $\mathrm{Ag}$ / $\mathrm{AgNO}_{3}$ pseudo reference electrode ( $\mathrm{CH}$ Instruments). Potentials are reported relative to the ferrocenium/ferrocene couple, the position of which was judged by adding ferrocene to the samples analyzed. Working electrodes were washed with acetone and deionized water prior to use. Cyclic voltammograms were collected at room temperature under an atmosphere of $\mathrm{Ar}$ at a scan rate of $100 \mathrm{mV} \mathrm{s}^{-1}$, unless otherwise noted. A glassy-carbon button electrode (area 0.071 $\mathrm{cm}^{2}, \mathrm{CH}$ Instruments) was used as the working electrode for cyclic voltammetry. The supporting electrolyte was $0.1 \mathrm{M}$ TBA$\mathrm{PF}_{6}$ in acetonitrile, unless otherwise noted. Measurements were conducted without stirring and with $i R$ compensation enabled. The $i R$ test function available on the $\mathrm{CH}$ potentiostats uses the general method developed by $\mathrm{He}$ and Faulkner. ${ }^{105}$ Bulk electrolyses were carried out in $0.2 \mathrm{M} \mathrm{TBA}-\mathrm{PF}_{6}$ in acetonitrile
$(15 \mathrm{~mL})$ in a sealed single-chamber cell (headspace volume 97 $\mathrm{mL}$ ), using an $\mathrm{Ag} / \mathrm{AgNO}_{3}$ pseudo reference electrode, a Pt-wire counter electrode and a large-area glassy-carbon (CarbonVitreous 3000C (C) foil, $1.0 \mathrm{~mm}$ thickness, GoodFellow) foil electrode of area $4.6 \mathrm{~cm}^{2}$. Solutions were stirred during bulk electrolyses, which were conducted without considering any resistive losses; solution resistances were measured using the $i R$ test function (as for cyclic voltammetry) and were found to be on the order of 10-30 $\Omega$. At the currents typically passing in these experiments, the voltage drops caused by this uncompensated resistance were thus generally under $1 \mathrm{mV}$ and could be neglected.

Colorimetric NO Determination. The NO generated during bulk electrolysis was quantified in an airtight cell (headspace volume $97 \mathrm{~mL}$ ) in $0.2 \mathrm{M} \mathrm{TBA}^{-\mathrm{PF}_{6}}$ in acetonitrile (15 mL) using an $\mathrm{Ag} / \mathrm{AgNO}_{3}$ pseudo reference electrode, a Ptwire counter electrode, and a large-area glassy-carbon-foil working electrode (area $4.6 \mathrm{~cm}^{2}$ ). The concentration of compound 3 or compound 4 employed was $7 \times 10^{-6} \mathrm{M}$. The electrolyte also contained 120 equiv of benzoic acid and 120 equiv of TBA- $\mathrm{NO}_{2}$ relative to compound 3 or 4 . A control reaction was also performed containing these amounts of benzoic acid and TBA- $\mathrm{NO}_{2}$ but in the absence of any catalyst. A $14 \mathrm{~mL}$ vial was glued to the internal wall of the airtight cell above the level of the electrolyte solution, into which was placed $5 \mathrm{~mL}$ of an $8 \times 10^{-5} \mathrm{M}$ Co-TPP solution in dichloromethane, the concentration of which was crosschecked using the molar extinction coefficient reported by Berry and co-workers. ${ }^{106}$ The vial was left open at the top, so that NO in the headspace could diffuse into the Co-TPP solution, but the Co-TPP solution and the electrolyte could not mix. The electrolyte and headspace of the cell were thoroughly degassed with Ar for $30 \mathrm{~min}$ before initiation of electrolysis. Bulk electrolyses were then conducted at $-0.91 \mathrm{~V}$ (vs ferrocenium/ferrocene) with stirring. At the end of electrolysis, the solution continued to be stirred and the cell was left sealed for a further $2 \mathrm{~h}$, in order to allow time for $\mathrm{NO}$ in the headspace to diffuse fully into the Co-TPP solution. An aliquot of the CoTPP solution was then withdrawn from the $14 \mathrm{~mL}$ vial, and its electronic spectrum was measured. Given a Henry's Law coefficient for the solubility of $\mathrm{NO}$ in $\mathrm{CH}_{3} \mathrm{CN}$ at room temperature of $1.35 \times 10^{8} \mathrm{~Pa},{ }^{107}$ the amount of $\mathrm{NO}$ dissolved in solution was calculated to be negligible under these conditions and was thus ignored.

A calibration curve equating the shift in the position of the Co-TPP absorbance band at $\lambda_{\max } \sim 530 \mathrm{~nm}$ was constructed (see Figures S10 and S11), using a sealed cell configuration similar to that described above with a dichloromethane/CoTPP solution in an open vial attached to the inner wall of the cell, where the Co-TPP solution was not in contact with the liquid in the main cell. The main body of the cell was then purged with $\mathrm{Ar}$ and filled with $20 \mathrm{~mL}$ of a $50 \mathrm{mM}$ solution of ascorbic acid in glacial acetic acid $/ \mathrm{H}_{2} \mathrm{O}$ (respectively $18 \mathrm{~mL} / 2$ $\mathrm{mL}$ ), which is known to generate NO stoichiometrically from nitrite. ${ }^{108}$ Known aliquots of sodium nitrite (as a solution in water) were then added to this solution, which was then stirred in the sealed cell for $2 \mathrm{~h}$. After this time, an aliquot of the CoTPP solution was withdrawn from the $14 \mathrm{~mL}$ vial and its electronic spectrum was measured. From this, a graph of shift in $\lambda_{\max }$ vs amount of NO generated was constructed.

Quantification of Nitric Oxide Release by Chemiluminescence. Bulk electrolysis was conducted as for the colorimetric tests for $\mathrm{NO}$ in identical sealed cells. NO release 
measurements by chemiluminescence were then performed using a Sievers NOA 280i chemiluminescence nitric oxide analyzer. The instrument was calibrated by passing air through a zero filter (Sievers, <1 ppb NO) and $89.8 \mathrm{ppm}$ of NO gas (BOC, balance nitrogen). The flow rate was set to $200 \mathrm{~mL}$ $\mathrm{min}^{-1}$ with a cell pressure of 6.5 Torr and an oxygen pressure of 6.1 psig. To measure NO production, nitrogen gas was flushed through the electrochemical cell, the resultant gas directed into the analyzer, and the concentration of NO recorded. The limit of detection of this analyzer is $0.5 \mathrm{ppb}$.

Calculations. The program package ORCA was used for all calculations. ${ }^{109}$ The input geometry for all molecules were generated using ArgusLab. The geometries of all molecules were fully optimized by a spin-unrestricted DFT method employing the BP86 functional with acetonitrile as solvent. ${ }^{110,111}$ Split-valence basis sets with one set of polarization functions (def2-SVP) were used for all atoms. ${ }^{112,113}$ A scalar relativistic correction was applied using the zeroth-order regular approximation (ZORA) method. ${ }^{114-196}$ The RIJCOSX approximation combined with the appropriate Ahlrichs auxiliary basis set was used to speed up the calculations. ${ }^{117-119}$ The conductor-like screening model (COSMO) was used for all calculations. $^{120}$ The self-consistent field calculations were tightly converged $\left(1 \times 10^{-8} E_{\mathrm{h}}\right.$ in energy, $1 \times 10^{-7} E_{\mathrm{h}}$ in the charge density, and $1 \times 10^{-7}$ in the maximum element of the DIIS $^{121,122}$ error vector). The geometry was converged with the following convergence criteria: change in energy $<10^{-5} E_{\mathrm{h}}$, average force $<5 \times 10^{-4} E_{\mathrm{h}} \mathrm{Bohr}^{-1}$, and maximum force $10^{-4} E_{\mathrm{h}}$ $\mathrm{Bohr}^{-1}$. The geometry search for all complexes was carried out in redundant internal coordinates without imposing geometry constraints. The stability of all solutions was checked by performing frequency calculations: no negative frequencies were observed. Single-point calculations were performed on optimized coordinates using the PBE0 functional ${ }^{123,124}$ and triple- $\zeta$-quality basis sets with one set of polarization functions (def2-TZVP) for all atoms. ${ }^{111}$

\section{ASSOCIATED CONTENT}

\section{S Supporting Information}

The Supporting Information is available free of charge on the ACS Publications website at DOI: 10.1021/acscatal.8b00361.

Additional NMR, EPR, and electrochemical characterization, additional NO quantification analyses, full crystallographic information, and the geometry optimized coordinates from the DFT calculations (PDF) Crystallographic data (CIF)

Crystallographic data (CIF)

\section{AUTHOR INFORMATION}

\section{Corresponding Author}

*E-mail for M.D.S.: mark.symes@glasgow.ac.uk.

ORCID

Stephen Sproules: 0000-0003-3587-0375

Mark D. Symes: 0000-0001-8067-5240

\section{Author Contributions}

${ }^{\S}$ G.C. and I.R. contributed equally to this work.

\section{Author Contributions}

G.C. and I.R. performed the synthesis and characterization of the compounds and undertook the electrochemical and spectroscopic NO quantification studies. G.C., I.R., and P.S.W. performed NO quantification studies using the Sievers
NO analysis system. C.W. carried out the single crystal crystallographic studies. S.S. performed the EPR experiments and the DFT calculations. M.D.S. conceived the idea and planned the required experiments, and M.D.S. and R.E.M. supervised the work. The manuscript was written through the contributions of all the authors and all the authors have given approval to the final version of the manuscript.

\section{Notes}

The authors declare no competing financial interest.

\section{ACKNOWLEDGMENTS}

This work was supported by the EPSRC (Grant No. EP/ K031732/1) and the Royal Society (University Research Fellowship UF150104 to M.D.S.). The data which underpin this work are available at http://dx.doi.org/10.5525/gla. researchdata.590 and are available under a CC-BY licence.

\section{REFERENCES}

(1) Cosby, K.; Partovi, K. S.; Crawford, J. H.; Patel, R. P.; Reiter, C. D.; Martyr, S.; Yang, B. K.; Waclawiw, M. A.; Zalos, G.; Xu, X.; Huang, K. T.; Shields, H.; Kim-Shapiro, D. B.; Schechter, A. N.; Cannon, R. O., III; Gladwin, M. T. Nitrite Reduction to Nitric Oxide by Deoxyhemoglobin Vasodilates the Human Circulation. Nat. Med. 2003, 9, 1498-1505.

(2) Calabrese, V.; Mancuso, C.; Calvani, M.; Rizzarelli, E.; Butterfield, D. A.; Giuffrida Stella, A. M. Nitric Oxide in the Central Nervous System: Neuroprotection Versus Neurotoxicity. Nat. Rev. Neurosci. 2007, 8, 766-775.

(3) Omar, S. A.; Webb, A. J. Nitrite Reduction and Cardiovascular Protection. J. Mol. Cell. Cardiol. 2014, 73, 57-69.

(4) Heinecke, J.; Ford, P. C. Mechanistic Studies of Nitrite Reactions with Metalloproteins and Models Relevant to Mammalian Physiology. Coord. Chem. Rev. 2010, 254, 235-247.

(5) Maia, L. B.; Moura, J. J. G. How Biology Handles Nitrite. Chem. Rev. 2014, 114, 5273-5357.

(6) Averill, B. A. Dissimilatory Nitrite and Nitric Oxide Reductases. Chem. Rev. 1996, 96, 2951-2964.

(7) Godden, J. W.; Turley, S.; Teller, D. C.; Adman, E. T.; Liu, M. Y.; Payne, W. J.; LeGall, J. The 2.3 Angstrom X-Ray Structure of Nitrite Reductase from Achromobacter Cycloclastes. Science 1991, 253, 438442.

(8) Tocheva, E. I.; Rosell, F. I.; Mauk, A. G.; Murphy, M. E. P. SideOn Copper-Nitrosyl Coordination by Nitrite Reductase. Science 2004, 304, 867-870.

(9) Halsted, T. P.; Yamashita, K.; Hirata, K.; Ago, H.; Ueno, G.; Tosha, T.; Eady, R. R.; Antonyuk, S. V.; Yamamoto, M.; Hasnain, S. S. An Unprecedented Dioxygen Species Revealed by Serial Femtosecond Rotation Crystallography in Copper Nitrite Reductase. IUCrJ 2018, 5, $22-31$.

(10) Ghosh, S.; Dey, A.; Sun, Y.; Scholes, C. P.; Solomon, E. I. Spectroscopic and Computational Studies of Nitrite Reductase: Proton Induced Electron Transfer and Backbonding Contributions to Reactivity. J. Am. Chem. Soc. 2009, 131, 277-288.

(11) Wasser, I. M.; de Vries, S.; Moënne-Loccoz, P.; Schröder, I.; Karlin, K. D. Nitric Oxide in Biological Denitrification: $\mathrm{Fe} / \mathrm{Cu}$ Metalloenzyme and Metal Complex $\mathrm{NO}_{x}$ Redox Chemistry. Chem. Rev. 2002, 102, 1201-1234.

(12) Merkle, A. C.; Lehnert, N. Binding and Activation of Nitrite and Nitric Oxide by Copper Nitrite Reductase and Corresponding Model Complexes. Dalton Trans. 2012, 41, 3355-3368.

(13) Timmons, A. J.; Symes, M. D. Converting between the Oxides of Nitrogen Using Metal-Ligand Coordination Complexes. Chem. Soc. Rev. 2015, 44, 6708-6722.

(14) Rosca, V.; Duca, M.; de Groot, M. T.; Koper, M. T. M. Nitrogen Cycle Electrocatalysis. Chem. Rev. 2009, 109, 2209-2244. 
(15) Tolman, W. B. A Model for the Substrate Adduct of Copper Nitrite Reductase and its Conversion to a Novel Tetrahedral Copper(II) Triflate Complex. Inorg. Chem. 1991, 30, 4877-4880.

(16) Casella, L.; Carugo, O.; Gullotti, M.; Doldi, S.; Frassoni, M. Synthesis, Structure, and Reactivity of Model Complexes of Copper Nitrite Reductase. Inorg. Chem. 1996, 35, 1101-1113.

(17) Ruggiero, C. E.; Carrier, S. M.; Tolman, W. B. Reductive Disproportionation of NO Mediated by Copper Complexes: Modeling $\mathrm{N}_{2} \mathrm{O}$ Generation by Copper Proteins and Heterogeneous Catalysts. Angew. Chem., Int. Ed. Engl. 1994, 33, 895-897.

(18) Paul, P. P.; Tyeklar, Z.; Farooq, A.; Karlin, K. D.; Liu, S.; Zubieta, J. Isolation and X-Ray Structure of a Dinuclear CopperNitrosyl Complex. J. Am. Chem. Soc. 1990, 112, 2430-2432.

(19) Paul, P. P.; Karlin, K. D. Functional Modeling of copper Nitrite Reductases: Reactions of $\mathrm{NO}_{2}^{-}$or Nitric Oxide with Copper(I) Complexes. J. Am. Chem. Soc. 1991, 113, 6331-6332.

(20) Carrier, S. M.; Ruggiero, C. E.; Tolman, W. B.; Jameson, G. B. Synthesis and Structural Characterization of a Mononuclear Copper Nitrosyl Complex. J. Am. Chem. Soc. 1992, 114, 4407-4408.

(21) Schneider, J. L.; Carrier, S. M.; Ruggiero, C. E.; Young, V. G., Jr.; Tolman, W. B. Influences of Ligand Environment on the Spectroscopic Properties and Disproportionation Reactivity of Copper-Nitrosyl Complexes. J. Am. Chem. Soc. 1998, 120, 1140811418.

(22) Halfen, J. A.; Mahapatra, S.; Olmstead, M. M.; Tolman, W. B. Synthetic Analogs of Nitrite Adducts of Copper Proteins: Characterization and Interconversion of Dicopper(II) and -(I,II) Complexes Bridged only by $\mathrm{NO}_{2}^{-}$. J. Am. Chem. Soc. 1994, 116, 2173-2174.

(23) Halfen, J. A.; Mahapatra, S.; Wilkinson, E. C.; Gengenbach, A. J.; Young, V. G., Jr.; Que, L., Jr.; Tolman, W. B. Synthetic Modeling of Nitrite Binding and Activation by Reduced Copper Proteins. Characterization of Copper(I)-Nitrite Complexes that Evolve Nitric Oxide. J. Am. Chem. Soc. 1996, 118, 763-776.

(24) Kujime, M.; Fujii, H. Spectroscopic Characterization of Reaction Intermediates in a Model for Copper Nitrite Reductase. Angew. Chem., Int. Ed. 2006, 45, 1089-1092.

(25) Kujime, M.; Izumi, C.; Tomura, M.; Hada, M.; Fujii, H. Effect of a Tridentate Ligand on the Structure, Electronic Structure, and Reactivity of the Copper(I) Nitrite Complex: Role of the Conserved Three-Histidine Ligand Environment of the Type-2 Copper Site in Copper-Containing Nitrite Reductases. J. Am. Chem. Soc. 2008, 130, 6088-6098.

(26) Hsu, S. C. N.; Chang, Y.-L.; Chuang, W.-J.; Chen, H.-Y.; Lin, I.J.; Chiang, M. Y.; Kao, C.-L.; Chen, H.-Y. Copper(I) Nitro Complex with an Anionic $\left[\mathrm{HB}\left(3,5-\mathrm{Me}_{2} \mathrm{Pz}\right)_{3}\right]^{-}$Ligand: A Synthetic Model for the Copper Nitrite Reductase Active Site. Inorg. Chem. 2012, 51, 9297-9308.

(27) Woollard-Shore, J. G.; Holland, J. P.; Jones, M. W.; Dilworth, J. R. Nitrite Reduction by Copper Complexes. Dalton Trans. 2010, 39, $1576-1585$.

(28) Maji, R. C.; Barman, S. K.; Roy, S.; Chatterjee, S. K.; Bowles, F. L.; Olmstead, M. M.; Patra, A. K. Copper Complexes Relevant to the Catalytic Cycle of Copper Nitrite Reductase: Electrochemical Detection of $\mathrm{NO}(\mathrm{g})$ Evolution and Flipping of $\mathrm{NO}_{2}$ Binding Mode upon $\mathrm{Cu}^{\mathrm{II}} \rightarrow \mathrm{Cu}^{\mathrm{I}}$ Reduction. Inorg. Chem. 2013, 52, 11084-11095.

(29) Kumar, M.; Dixon, N. A.; Merkle, A. C.; Zeller, M.; Lehnert, N.; Papish, E. T. Hydrotris(triazolyl)borate Complexes as Functional Models for $\mathrm{Cu}$ Nitrite Reductase: The Electronic Influence of Distal Nitrogens. Inorg. Chem. 2012, 51, 7004-7006.

(30) Lehnert, N.; Cornelissen, U.; Neese, F.; Ono, T.; Noguchi, Y.; Okamoto, K.-i.; Fujisawa, K. Synthesis and Spectroscopic Characterization of Copper(II)-Nitrito Complexes with Hydrotris(pyrazolyl)borate and Related Coligands. Inorg. Chem. 2007, 46, 3916-3933.

(31) Hematian, S.; Siegler, M. A.; Karlin, K. D. Heme/Copper Assembly Mediated Nitrite and Nitric Oxide Interconversion. J. Am. Chem. Soc. 2012, 134, 18912-18915.

(32) Sakhaei, Z.; Kundu, S.; Donnelly, J. M.; Bertke, J. A.; Kim, W. K.; Warren, T. H. Nitric Oxide Release via Oxygen Atom Transfer from Nitrite at Copper(II). Chem. Commun. 2017, 53, 549-552.
(33) Scarpellini, M.; Neves, A.; Castellano, E. E.; de Almeida Neves, E. F.; Franco, D. W. A Structural Model for Oxidized Type II Copper Nitrite Reductase with a Polyimidazole Tripodal Ligand. Polyhedron 2004, 23, 511-518.

(34) Burg, A.; Lozinsky, E.; Cohen, H.; Meyerstein, D. Mechanism of Reduction of the Nitrite Ion by $\mathrm{Cu}^{\mathrm{I}}$ Complexes. Eur. J. Inorg. Chem. 2004, 3675-3680.

(35) Fujisawa, K.; Tateda, A.; Miyashita, Y.; Okamoto, K.-i.; Paulat, F.; Praneeth, V. K. K.; Merkle, A.; Lehnert, N. Structural and Spectroscopic Characterization of Mononuclear Copper(I) Nitrosyl Complexes: End-On versus Side-On Coordination of NO to Copper(I). J. Am. Chem. Soc. 2008, 130, 1205-1213.

(36) Kundu, S.; Kim, W. Y.; Bertke, J. A.; Warren, T. H. Copper(II) Activation of Nitrite: Nitrosation of Nucleophiles and Generation of NO by Thiols. J. Am. Chem. Soc. 2017, 139, 1045-1048.

(37) Chen, C.-S.; Dai, H.-F.; Chen, C.-H.; Yeh, W.-Y. Synthesis, Characterization and Protonation Reaction of Copper and Palladium Complexes Bearing Nitrite Ligands in O,O-bidentate and $\mathrm{N}$ monodentate Bonding Fashions. Inorg. Chim. Acta 2011, 376, 396400.

(38) Monzani, E.; Koolhaas, G. J. A. A.; Spandre, A.; Leggieri, E.; Casella, L.; Gullotti, M.; Nardin, G.; Randaccio, L.; Fontani, M.; Zanello, P.; Reedijk, J. Binding of Nitrite and its Reductive Activation to Nitric Oxide at Biomimetic Copper Centers. JBIC, J. Biol. Inorg. Chem. 2000, 5, 251-261.

(39) Beretta, M.; Bouwman, E.; Casella, L.; Douziech, B.; Driessen, W. L.; Gutierrez-Soto, L.; Monzani, E.; Reedijk, J. Copper Complexes of a new Tridentate Imidazole-Containing Ligand: Spectroscopy, Structures and Nitrite Reductase Reactivity: The Molecular Structures of $\left[\mathrm{Cu}\right.$ (biap) $\left.\left(\mathrm{NO}_{2}\right)_{2}\right]$ and $\left[\mathrm{Cu}\right.$ (biap) $\left.\mathrm{Br}_{2}\right]$. Inorg. Chim. Acta 2000, 310, $41-50$.

(40) Chuang, W.-J.; Lin, I.-J.; Chen, H.-Y.; Chang, Y.-L.; Hsu, S. C. N. Characterization of a New Copper(I)-Nitrito Complex that Evolves Nitric Oxide. Inorg. Chem. 2010, 49, 5377-5384.

(41) Chen, C.-S.; Yeh, W.-Y. Coordination of $\mathrm{NO}_{2}{ }^{-}$Ligand to $\mathrm{Cu}(\mathrm{I})$ Ion in an O,O-Bidentate Fashion that Evolves $\mathrm{NO}$ Gas upon Protonation: A Model Reaction Relevant to the Denitrification Process. Chem. Commun. 2010, 46, 3098-3100.

(42) Roger, I.; Wilson, C.; Senn, H. M.; Sproules, S.; Symes, M. D. An Investigation into the Unusual Linkage Isomerization and Nitrite Reduction Activity of a Novel Tris(2-pyridyl) Copper Complex. R. Soc. Open Sci. 2017, 4, 170593.

(43) Komeda, N.; Nagao, H.; Kushi, Y.; Adachi, G.-y.; Suzuki, M.; Uehara, A.; Tanaka, K. Molecular Structure of Nitro- and NitritoCopper Complexes as Reaction Intermediates in Electrochemical Reduction of Nitrite to Dinitrogen Oxide. Bull. Chem. Soc. Jpn. 1995, $68,581-589$.

(44) Tegoni, M.; Yu, F.; Bersellini, M.; Penner-Hahn, J. E.; Pecoraro, V. L. Designing a Functional Type 2 Copper Center that has Nitrite Reductase Activity within $\alpha$-Helical Coiled Coils. Proc. Natl. Acad. Sci. U. S. A. 2012, 109, 21234-21239.

(45) Koebke, K. J.; Yu, F.; Salerno, E.; Stappen, C. V.; Tebo, A. G.; Penner-Hahn, J. E.; Pecoraro, V. L. Modifying the Steric Properties in the Second Coordination Sphere of Designed Peptides Leads to Enhancement of Nitrite Reductase Activity. Angew. Chem., Int. Ed. 2018, 57, 3954-3957.

(46) Nagao, H.; Komeda, N.; Mukaida, M.; Suzuki, M.; Tanaka, K. Structural and Electrochemical Comparison of Copper(II) Complexes with Tripodal Ligands. Inorg. Chem. 1996, 35, 6809-6815.

(47) Orain, C.; Porras-Gutiérrez, A. G.; Evoung Evoung, F.; Charles, C.; Cosquer, N.; Gomila, A.; Conan, F.; Le Mest, Y.; Le Poul, N. Electrocatalytic Reduction of Nitrite Ions by a Copper Complex Attached as SAMs on Gold by "Self-Induced Electroclick": Enhancement of the Catalytic Rate by Surface Coverage Decrease. Electrochem. Commun. 2013, 34, 204-207.

(48) Hiratsu, T.; Suzuki, S.; Yamaguchi, K. Electroreduction of Nitrite on Gold Electrodemodified with $\mathrm{Cu}$-Containing Nitrite Reductase Model Complex. Chem. Commun. 2005, 4534-4535. 
(49) Isoda, N.; Yokoyama, H.; Nojiri, M.; Suzuki, S.; Yamaguchi, K. Electroreduction of Nitrite to Nitrogen Oxide by a Copper-Containing Nitrite Reductase Model Complex Incorporated into Collagen Film. Bioelectrochemistry 2010, 77, 82-88.

(50) Migita, Y.; Yokoyama, H.; Minami, A.; Mori, T.; Nojiri, M.; Suzuki, S.; Yamaguchi, K. Electrocatalytic Nitrite Reduction to Nitrogen Oxide by a Synthetic Analogue of the Active Site of $\mathrm{Cu}$ Containing Nitrite Reductase Incorporated in Nafion Film. Electroanalysis 2009, 21, 2441-2446.

(51) Siek, S.; Dixon, N. A.; Papish, E. T. Electrochemical reduction of Ttz copper(II) complexes in the presence and absence of protons: Processes Relevant to Enzymatic Nitrite Reduction $\left(T t z R, R^{\prime}=\operatorname{tris}(3-R\right.$, 5-R'-1, 2, 4-triazolyl)borate). Inorg. Chim. Acta 2017, 459, 80-86.

(52) Weinberg, D. R.; Gagliardi, C. J.; Hull, J. F.; Murphy, C. F.; Kent, C. A.; Westlake, B. C.; Paul, A.; Ess, D. H.; McCafferty, D. G.; Meyer, T. J. Proton-Coupled Electron Transfer. Chem. Rev. 2012, 112, 4016-4093.

(53) Reece, S. Y.; Nocera, D. G. Proton-Coupled Electron Transfer in Biology: Results from Synergistic Studies in Natural and Model Systems. Annu. Rev. Biochem. 2009, 78, 673-699.

(54) Koper, M. T. M. Theory of Multiple Proton-Electron Transfer Reactions and its Implications for Electrocatalysis. Chem. Sci. 2013, 4, $2710-2723$.

(55) Hammes-Schiffer, S. Proton-Coupled Electron Transfer: Moving Together and Charging Forward. J. Am. Chem. Soc. 2015, 137, 8860-8871.

(56) Gentry, E. C.; Knowles, R. R. Synthetic Applications of ProtonCoupled Electron Transfer. Acc. Chem. Res. 2016, 49, 1546-1556.

(57) Fukuda, Y.; Tse, K. M.; Nakane, T.; Nakatsu, T.; Suzuki, M.; Sugahara, M.; Inoue, S.; Masuda, T.; Yumoto, F.; Matsugaki, N.; Nango, E.; Tono, K.; Joti, Y.; Kameshima, T.; Song, C.; Hatsui, T.; Yabashi, M.; Nureki, O.; Murphy, M. E. P.; Inoue, T.; Iwata, S.; Mizohata, E. Redox-Coupled Proton Transfer Mechanism in Nitrite Reductase Revealed by Femtosecond Crystallography. Proc. Natl. Acad. Sci. U. S. A. 2016, 113, 2928-2933.

(58) Berry, S. M.; Strange, J. N.; Bladholm, E. L.; Khatiwada, B.; Hedstrom, C. G.; Sauer, A. M. Nitrite Reductase Activity in Engineered Azurin Variants. Inorg. Chem. 2016, 55, 4233-4247.

(59) Matson, E. M.; Park, Y. J.; Fout, A. R. Facile Nitrite Reduction in a Non-Heme Iron System: Formation of an Iron(III)-Oxo. J. Am. Chem. Soc. 2014, 136, 17398-17401.

(60) Kwon, Y. M.; Delgado, M.; Zakharov, L. N.; Seda, T.; Gilbertson, J. D. Nitrite Reduction by a Pyridinediimine Complex with a Proton-Responsive Secondary Coordination Sphere. Chem. Commun. 2016, 52, 11016-11019.

(61) Moore, C. M.; Szymczak, N. K. Nitrite Reduction by Copper Through Ligand-Mediated Proton and Electron Transfer. Chem. Sci. 2015, 6, 3373-3377.

(62) Koshiba, K.; Yamauchi, K.; Sakai, K. A Nickel Dithiolate Water Reduction Catalyst Providing Ligand-Based Proton-Coupled ElectronTransfer Pathways. Angew. Chem., Int. Ed. 2017, 56, 4247-4251.

(63) Horvath, S.; Fernandez, L. E.; Appel, A. M.; Hammes-Schiffer, S. $\mathrm{pH}$-Dependent Reduction Potentials and Proton-Coupled Electron Transfer Mechanisms in Hydrogen-Producing Nickel Molecular Electrocatalysts. Inorg. Chem. 2013, 52, 3643-3652.

(64) Helm, M. L.; Stewart, M. P.; Bullock, R. M.; Rakowski DuBois, M.; DuBois, D. L. A Synthetic Nickel Electrocatalyst with a Turnover Frequency above $100,000 \mathrm{~s}^{-1}$ for $\mathrm{H}_{2}$ Production. Science 2011, 333, $863-866$.

(65) O’Hagan, M.; Shaw, W. J.; Raugei, S.; Chen, S.; Yang, J. Y.; Kilgore, U. J.; DuBois, D. L.; Bullock, R. M. Moving Protons with Pendant Amines: Proton Mobility in a Nickel Catalyst for Oxidation of Hydrogen. J. Am. Chem. Soc. 2011, 133, 14301-14312.

(66) Berning, D. E.; Noll, B. C.; DuBois, D. L. Relative Hydride, Proton, and Hydrogen Atom Transfer Abilities of [HM(diphosphine $\left.)_{2}\right] \mathrm{PF}_{6}$ Complexes $(\mathrm{M}=\mathrm{Pt}, \mathrm{Ni})$. J. Am. Chem. Soc. 1999, 121, 11432-11447.
(67) Lee, C. H.; Dogutan, D. K.; Nocera, D. G. Hydrogen Generation by Hangman Metalloporphyrins. J. Am. Chem. Soc. 2011, 133, 8775-8777.

(68) Dogutan, D. K.; McGuire, R., Jr.; Nocera, D. G. Electocatalytic Water Oxidation by Cobalt(III) Hangman $\beta$-Octafluoro Corroles. J. Am. Chem. Soc. 2011, 133, 9178-9180.

(69) Gagliardi, C. J.; Vannucci, A. K.; Concepcion, J. J.; Chen, Z.; Meyer, T. J. The Role of Proton Coupled Electron Transfer in Water Oxidation. Energy Environ. Sci. 2012, 5, 7704-7717.

(70) Symes, M. D.; Surendranath, Y.; Lutterman, D. A.; Nocera, D. G. Bidirectional and Unidirectional PCET in a Molecular Model of a Cobalt-Based Oxygen-Evolving Catalyst. J. Am. Chem. Soc. 2011, 133, 5174-5177.

(71) Costentin, C.; Drouet, S.; Robert, M.; Savéant, J.-M. A Local Proton Source Enhances $\mathrm{CO}_{2}$ Electroreduction to $\mathrm{CO}$ by a Molecular Fe Catalyst. Science 2012, 338, 90-94.

(72) Costentin, C.; Passard, G.; Robert, M.; Savéant, J.-M. Pendant Acid-Base Groups in Molecular Catalysts: H-Bond Promoters or Proton Relays? Mechanisms of the Conversion of $\mathrm{CO}_{2}$ to $\mathrm{CO}$ by Electrogenerated Iron(0)Porphyrins Bearing Prepositioned Phenol Functionalities. J. Am. Chem. Soc. 2014, 136, 11821-11829.

(73) Cervantes, F. J.; De la Rosa, D. A.; Gómez, J. Nitrogen Removal from Wastewaters at Low C/N Ratios with Ammonium and Acetate as Electron Donors. Bioresour. Technol. 2001, 79, 165-170.

(74) Ren, H.; Wu, J.; Xi, C.; Lehnert, N.; Major, T.; Bartlett, R. H.; Meyerhoff, M. E. Electrochemically Modulated Nitric Oxide (NO) Releasing Biomedical Devices via Copper(II)-Tri(2-Pyridylmethyl)Amine Mediated Reduction of Nitrite. ACS Appl. Mater. Interfaces 2014, 6, 3779-3783.

(75) Mato-Iglesias, M.; Roca-Sabio, A.; Pálinkás, Z.; Esteban-Gómez, D.; Platas-Iglesias, C.; Tóth, E.; de Blas, A.; Rodríguez-Blas, T. Lanthanide Complexes Based on a 1,7-Diaza-12-Crown-4 Platform Containing Picolinate Pendants: A new Structural Entry for the Design of Magnetic Resonance Imaging Contrast Agents. Inorg. Chem. 2008, 47, 7840-7851.

(76) Kotani, H.; Kaida, S.; Ishizuka, T.; Sakaguchi, M.; Ogura, T.; Shiota, Y.; Yoshizawa, K.; Kojima, T. Formation and Characterization of a Reactive Chromium(V)-Oxo Complex: Mechanistic Insight into Hydrogen-Atom Transfer Reactions. Chem. Sci. 2015, 6, 945-955.

(77) Kojima, T.; Hirai, Y.; Ishizuka, T.; Shiota, Y.; Yoshizawa, K.; Ikemura, K.; Ogura, T.; Fukuzumi, S. A Low-Spin Ruthenium(IV)Oxo Complex: Does the Spin State Have an Impact on the Reactivity? Angew. Chem., Int. Ed. 2010, 49, 8449-8453.

(78) Jacobson, R. R.; Tyeklar, Z.; Karlin, K. D.; Zubieta, J. Fluoride as a Terminal and Bridging Ligand for Copper: Isolation and X-Ray Crystallographic Characterization of Copper Monomeric and Dimeric Complexes $\left[\mathrm{Cu}^{\mathrm{II}}(\mathrm{TMPA}) \mathrm{F}\right]_{\mathrm{n}}{ }^{\mathrm{n}+}(\mathrm{n}=1$ or 2 ; TMPA $=\operatorname{Tris}[(2-$ pyridyl)methyl] amine. Inorg. Chem. 1991, 30, 2035-2040.

(79) Tyeklár, Z.; Jacobson, R. R.; Wei, N.; Murthy, N. N.; Zubieta, J.; Karlin, K. D. Reversible Reaction of Dioxygen (and Carbon Monoxide) with a Copper(I) Complex. X-Ray Structures of Relevant Mononuclear $\mathrm{Cu}(\mathrm{I})$ Precursor Adducts and the Trans-( $\mu$-1,2-peroxo)dicopper(II) Product. J. Am. Chem. Soc. 1993, 115, 2677-2689.

(80) Le Poul, N.; Douziech, B.; Zeitouny, J.; Thiabaud, G.; Colas, H.; Conan, F.; Cosquer, N.; Jabin, I.; Lagrost, C.; Hapiot, P.; Reinaud, O.; Le Mest, Y. Mimicking the Protein Access Channel to a Metal Center: Effect of a Funnel Complex on Dissociative versus Associative Copper Redox Chemistry. J. Am. Chem. Soc. 2009, 131, 17800-17807.

(81) Karlin, K. D.; Hayes, J. C.; Juen, S.; Hutchinson, J. P.; Zubieta, J. Tetragonal vs. Trigonal Coordination in Copper(II) Complexes with Tripod Ligands: Structures and Properties of $\left[\mathrm{Cu}\left(\mathrm{C}_{21} \mathrm{H}_{24} \mathrm{~N}_{4}\right) \mathrm{Cl}\right] \mathrm{PF}_{6}$ and $\left[\mathrm{Cu}\left(\mathrm{C}_{18} \mathrm{H}_{18} \mathrm{~N}_{4}\right) \mathrm{Cl}\right] \mathrm{PF}_{6}$. Inorg. Chem. 1982, 21, 4106-4108.

(82) Addison, A. W.; Rao, T. N.; Reedijk, J.; van Rijn, J.; Verschoor, G. C. Synthesis, Structure, and Spectroscopic Properties of Copper(II) Compounds Containing Nitrogen-Sulphur Donor Ligands; the Crystal and Molecular Structure of Aqua[1,7-bis $(\mathrm{N}$-methylbenzimidazol-2'-yl)-2,6-dithiaheptane]Copper(II) Perchlorate. J. Chem. Soc., Dalton Trans. 1984, 1349-1356. 
(83) Symes, M. D.; Wilson, C. Probing the Effects of Steric Bulk on the Solution-Phase Behaviour and Redox Chemistry of Cobalt-Diimine Complexes. Supramol. Chem. 2017, 1.

(84) Izzet, G.; Zeng, X.; Akdas, H.; Marrot, J.; Reinaud, O. Drastic Effects of the Second Coordination Sphere on Neutral vs. Anionic Guest Binding to a Biomimetic $\mathrm{Cu}(\mathrm{II})$ Center Embedded in a Calix[6]aza-Cryptand. Chem. Commun. 2007, 810-812.

(85) Lonnon, D. G.; Craig, D. C.; Colbran, S. B. An Unusual but Informative Synthesis and the Crystal Structure of $\left[\mathrm{Co}\left(\mathrm{tpaCO}_{2}\right) \mathrm{Cl}\right]$ $\left(\mathrm{ClO}_{4}\right) \quad\left(\mathrm{tpaCO}_{2}{ }^{-}=6\right.$-carboxylato-2- (pyridylmethyl)-bis (2pyridylmethyl)amine. Inorg. Chem. Commun. 2003, 6, 1351-1353.

(86) Hayashi, H.; Uozumi, K.; Fujinami, S.; Nagatomo, S.; Shiren, K.; Furutachi, H.; Suzuki, M.; Uehara, A.; Kitagawa, T. Modulation of the Copper-Dioxygen Reactivity by Stereochemical Effect of Tetradentate Tripodal Ligands. Chem. Lett. 2002, 31, 416-417.

(87) Mizuno, M.; Honda, K.; Cho, J.; Furutachi, H.; Tosha, T.; Matsumoto, T.; Fujinami, S.; Kitagawa, T.; Suzuki, M. A Mononuclear Alkylperoxocopper(II) Complex as a Reaction Intermediate in the Oxidation of the Methyl Group of the Supporting Ligand. Angew. Chem., Int. Ed. 2006, 45, 6911-6914.

(88) Comba, P.; Grimm, L.; Orvig, C.; Rück, K.; Wadepohl, H. Synthesis and Coordination Chemistry of Hexadentate Picolinic Acid Based Bispidine Ligands. Inorg. Chem. 2016, 55, 12531-12543.

(89) Comba, P.; Jakob, M.; Rück, K.; Wadepohl, H. Tuning of the Properties of a Picolinic Acid-Based Bispidine Ligand for Stable Copper(II) Complexation. Inorg. Chim. Acta 2017, DOI: 10.1016/ j.ica.2017.08.022.

(90) Adler, A. D.; Longo, F. R.; Finarelli, J. D.; Goldmacher, J.; Assour, J.; Korsakoff, L. A Simplified Synthesis for MesoTetraphenylporphine. J. Org. Chem. 1967, 32, 476-476.

(91) Anderson, C. E.; Vagin, S. I.; Xia, W.; Jin, H.; Rieger, B. Cobaltoporphyrin-Catalyzed $\mathrm{CO}_{2}$ /Epoxide Copolymerization: Selectivity Control by Molecular Design. Macromolecules 2012, 45, 68406849.

(92) Mori, S.; Ishii, K.; Hirakawa, Y.; Nakamura, R.; Hashimoto, K. In Vivo Participation of Artificial Porphyrins in Electron-Transport Chains: Electrochemical and Spectroscopic Analyses of Microbial Metabolism. Inorg. Chem. 2011, 50, 2037-2039.

(93) Zheng, L.; Ye, D.; Xiong, L.; Xu, J.; Tao, K.; Zou, Z.; Huang, D.; Kang, X.; Yang, S.; Xia, J. Preparation of Cobalt-Tetraphenylporphyrin/Reduced Graphene Oxide Nanocomposite and its Application on Hydrogen Peroxide Biosensor. Anal. Chim. Acta 2013, 768, 69-75.

(94) Richter-Addo, G. B.; Hodge, S. J.; Yi, G.-B.; Khan, M. A.; Ma, T.; Van Caemelbecke, E.; Guo, N.; Kadish, K. M. Synthesis, Characterization, and Spectroelectrochemistry of Cobalt Porphyrins Containing Axially Bound Nitric Oxide. Inorg. Chem. 1996, 35, 65306538.

(95) Wijma, H. J.; Jeuken, L. J. C.; Verbeet, M. P.; Armstrong, F. A. Canters, G. W. A Random-Sequential Mechanism for Nitrite Binding and Active Site Reduction in Copper-Containing Nitrite Reductase. J. Biol. Chem. 2006, 281, 16340-16346.

(96) Warren, J. J.; Tronic, T. A.; Mayer, J. M. Thermochemistry of Proton-Coupled Electron Transfer Reagents and its Implications. Chem. Rev. 2010, 110, 6961-7001.

(97) Hanson, G. R.; Gates, K. E.; Noble, C. J.; Griffin, M.; Mitchell, A.; Benson, S. XSophe-Sophe-XeprView ${ }^{\circledR}$. A Computer Simulation Software Suite (v. 1.1.3) for the Analysis of Continuous Wave EPR Spectra. J. Inorg. Biochem. 2004, 98 (98), 903-916.

(98) Palatinus, L.; Chapuis, G. SUPERFLIP - A Computer Program for the Solution of Crystal Structures by Charge Flipping in Arbitrary Dimensions. J. Appl. Crystallogr. 2007, 40, 786-790.

(99) Palatinus, L.; van der Lee, A. Symmetry Determination Following Structure Solution in P1. J. Appl. Crystallogr. 2008, 41, 975-984.

(100) Palatinus, L.; Prathapa, S. J.; van Smaalen, S. EDMA: A Computer Program for Topological Analysis of Discrete Electron Densities. J. Appl. Crystallogr. 2012, 45, 575-580.

(101) Sheldrick, G. M. Crystal Structure Refinement with SHELXL. Acta Crystallogr., Sect. C: Struct. Chem. 2015, 71, 3-8.
(102) Dolomanov, O. V.; Bourhis, L. J.; Gildea, R. J.; Howard, J. A. K.; Puschmann, H. OLEX2: A Complete Structure Solution, Refinement and Analysis Program. J. Appl. Crystallogr. 2009, 42, 339-341.

(103) Sheldrick, G. M. SHELXT - Integrated Space-Group and Crystal-Structure Determination. Acta Crystallogr., Sect. A: Found. Adv. 2015, 71, 3-8.

(104) Sheldrick, G. M. A Short History of SHELX. Acta Crystallogr., Sect. A: Found. Crystallogr. 2008, 64, 112-122.

(105) He, P.; Faulkner, L. R. Intelligent, Automatic Compensation of Solution Resistance. Anal. Chem. 1986, 58, 517-523.

(106) Yao, S. A.; Hansen, C. B.; Berry, J. F. A Convenient, HighYielding, Chromatography-Free Method for the Insertion of Transition Metal Acetates into Porphyrins. Polyhedron 2013, 58, 2-6.

(107) Shaw, A. W.; Vosper, A. J. Solubility of Nitric Oxide in Aqueous and Nonaqueous Solvents. J. Chem. Soc., Faraday Trans. 1 1977, 73, 1239-1244.

(108) Nagababu, E.; Rifkind, J. M. Measurement of Plasma Nitrite by Chemiluminescence. Methods Mol. Biol. 2010, 610, 41-49.

(109) Neese, F. The ORCA Program System. WIREs Comput. Mol. Sci. 2012, 2, 73-78.

(110) Becke, A. D. Density-Functional Exchange-Energy Approximation with Correct Asymptotic Behavior. Phys. Rev. A: At., Mol., Opt. Phys. 1988, 38, 3098-3100.

(111) Perdew, J. P. Density-Functional Approximation for the Correlation Energy of the Inhomogeneous Electron Gas. Phys. Rev. B: Condens. Matter Mater. Phys. 1986, 33, 8822-8824.

(112) Ahlrichs, R.; May, K. Contracted All-Electron Gaussian Basis Sets for Atoms Rb to Xe. Phys. Chem. Chem. Phys. 2000, 2, 943-945.

(113) Weigend, F.; Ahlrichs, R. Balanced Basis Sets of Split Valence, Triple Zeta Valence and Quadruple Zeta Valence Quality for $\mathrm{H}$ to Rn: Design and Assessment of Accuracy. Phys. Chem. Chem. Phys. 2005, 7, 3297-3305.

(114) van Lenthe, E.; Snijders, J. G.; Baerends, E. J. The Zero-Order Regular Approximation for Relativistic Effects: The Effect of SpinOrbit Coupling in Closed Shell Molecules. J. Chem. Phys. 1996, 105, 6505-6516.

(115) van Lenthe, J. H.; Faas, S.; Snijders, J. G. Gradients in the Ab Initio Scalar Zeroth-Order Regular Approximation (ZORA) approach. Chem. Phys. Lett. 2000, 328, 107-112.

(116) van Lenthe, E.; van der Avoird, A.; Wormer, P. E. S. Density Functional Calculations of Molecular Hyperfine Interactions in the Zero Order Regular Approximation for Relativistic Effects. J. Chem. Phys. 1998, 108, 4783-4796.

(117) Neese, F.; Wennmohs, F.; Hansen, A.; Becker, U. Efficient, Approximate and Parallel Hartree-Fock and Hybrid DFT Calculations. A 'Chain-Of-Spheres' Algorithm for the Hartree-Fock Exchange. Chem. Phys. 2009, 356, 98-109.

(118) Eichkorn, K.; Treutler, O.; Öhm, H.; Häser, M.; Ahlrichs, R. Auxiliary Basis Sets to Approximate Coulomb Potentials (Chem. Phys. Letters 240 (1995) 283). Chem. Phys. Lett. 1995, 242, 652-660.

(119) Eichkorn, K.; Weigend, F.; Treutler, O.; Ahlrichs, R. Auxiliary Basis Sets for Main Row Atoms and Transition Metals and their Use to Approximate Coulomb Potentials. Theor. Chem. Acc. 1997, 97, 119-124.

(120) Klamt, A.; Schüürmann, G. COSMO: a New Approach to Dielectric Screening in Solvents with Explicit Expressions for the Screening Energy and its Gradient. J. Chem. Soc., Perkin Trans. 2 1993, 799-805.

(121) Pulay, P. Convergence Acceleration of Iterative Sequences. The Case of scf Iteration. Chem. Phys. Lett. 1980, 73, 393-398.

(122) Pulay, P. Improved SCF Convergence Acceleration. J. Comput. Chem. 1982, 3, 556-560.

(123) Perdew, J. P.; Burke, K.; Ernzerhof, M. Generalized Gradient Approximation Made Simple. Phys. Rev. Lett. 1996, 77, 3865-3868.

(124) Adamo, C.; Barone, V. Toward Reliable Density Functional Methods without Adjustable Parameters: The PBE0Model. J. Chem. Phys. 1999, 110, 6158-6170. 